Egbert Fortuin

\title{
Universality and language-dependency of tense and aspect: Performatives from a crosslinguistic perspective
}

https://doi.org/10.1515/lingty-2018-0018

Received April 02, 2018; revised November 14, 2018

Abstract: This paper presents a cross-linguistic typology of performatives, especially with respect to their relationship with tense and aspect, in the languages of the world. I explore the relationship between performatives and particular tenses and aspects, and touch on the mechanisms underlying such a relationship. The paper finds that there is not one relation between performatives and a particular tense and aspect and there are no languages which have a special (dedicated) performative tense or aspect marker. Instead, performatives are compatible with various tense and aspect markers, even though the use of a present tense seems to be the most common. What counts as the most optimal tense and aspect for performatives depends on the division of labor within the linguistic structure.

Keywords: performatives, verbal aspect, tense, perfective, imperfective, comparative semantics

\section{Introduction}

Austin (1962) introduces performatives such as I promise as speech acts which not only describe a given reality, but also change the reality they are describing. Even though Austin argues that the simple present is directly or indirectly inherent to performatives in English, it was noted already in the first half of the twentieth century that some languages express performatives differently, for example by a perfective with a past reading (Koschmieder 1929, Koschmieder 1930 for Biblical Hebrew) or a verb which is morphologically marked as a perfective present tense (Škrabec 1903; Koschmieder 1929, Koschmieder 1930 for Slavic). Especially the use of the perfective past tense is surprising since performatives might be expected to require a form which can be used to refer to a present event such as a present tense form, or a non-past tense form. Even

Egbert Fortuin ['عybert for'tœyn], Leiden University Centre for Linguistics, Faculty of Humanities, Leiden University, Leiden, The Netherlands, E-mail: e.fortuin@hum.leidenuniv.nl

Ә Open Access. (C) 2019 Fortuin, published by De Gruyter. (c) BY-NC-ND This work is licensed under the Creative Commons Attribution-NonCommercial-NoDerivatives 4.0 License. 
though various authors have discussed or mentioned the tense and aspect of performatives from a general or crosslinguistic perspective (e.g. Koschmieder 1945; Dahl 1985; Hewson 2012; De Wit et al. 2018; Dickey 2000, Dickey 2015; Kamphuis 2012; Wiemer 2014 for Slavic; Hinrichs 1985, Hinrichs 1986 for the Balkan languages) scholars disagree about what the most frequent or preferred aspect and tense of performatives is, and how to explain the variety in tense, aspect and modality (TAM).

On the one hand, some linguists argue that performatives are inherently expressed by the imperfective. To give an example, Verschueren (1995: 317) remarks that in languages with a perfective/imperfective distinction such as Slavic, "the perfective would be used less-if at all-in a performative utterance". He interprets the perfective aspect of Slavic as (semantically and morphologically) marked, and since, being marked, it draws the attention more strongly to an interpretative difference between the linguistic action (i.e. the speech act) and the description (i.e. what is expressed by the verb), it is not in accordance with the function of a performative. Similarly, De Wit et al. (2018: $249,259)$ argue (on the basis of an insightful analysis of 16 languages) that languages with a general imperfective construction, like Slavic languages, systematically use this imperfective marker in performative utterances. Hewson (2012: 516-517) goes so far as to argue that there are no languages where performatives are expressed by a perfective at all. In his opinion, the perfective (also called "perfect") in languages such as Arabic is in fact better reanalysed as a "Performative", a label used by Hewson for forms which express "a complete performance in all phases of the event” (2012: 516) including states and total events, and which are reminiscent of Welmer's factative (see Section 4.1.3 below, for a more thorough discussion). In Hewson's view, languages with an actual perfective aspect such as Slavic never use the perfective in performatives since the perfective present form always has a future tense interpretation. This claim is, however, not in accordance with the use of the perfective present performative in Slovene, which has no future tense interpretation.

On the other hand, some linguists have argued that performatives are expressed by perfectives, and argue that performatives are in fact in full accordance with the semantics of perfectives. Bary $(2009$, 2012), on the basis of Ancient Greek data, claims for example that the optimal form for performatives would be the combination of present tense and aoristic (perfective) aspect, since event time and moment of utterance coincide (cf. Langacker 2001 for the English simple present). Dahl (1985: 81) in his comprehensive study of aspect from a crosslinguistic perspective also notices that performatives (on the basis of his sample of 64 languages, 45 of which have a perfective-imperfective distinction) are perfect candidates for a total event at the moment of speech and mentions 
that perfective performatives can be found in several languages. Dahl also suggests that those languages that employ a perfective performative, also generally seem to use a perfective in other instances where a complete (total) event coincides with the moment of speech such as reportive contexts where the speaker reports about dynamic events happening before his eyes, and other authors also pointed out that those languages which use a perfective performative, often use a perfective in contexts such as stage directions, recipes and the historical present (e.g. Koschmieder 1930; Dickey 2000; De Wit et al. 2018). Andrason (2012, 2016) provides a somewhat different approach and argues that perfective performatives such as in Biblical Hebrew and Mandinka (a Mande language spoken primarily in Senegal) can only be described in diachronic terms as remnants of older resultative uses. This differs from the point of view of Dekker (2018), who argues that (perfective) past tense performatives have an actual (perfective) past tense meaning.

Whereas there seems to be disagreement and at least unclarity about the use of the perfective and imperfective in performatives, there is general consensus that progressives are not suitable for performatives. Bybee and Dahl (1989: 82) notice for example that in Dahl's questionnaire of 64 languages the progressive is absent with performatives, and argue that the progressive as a universal grammatical type is incompatible with a performative reading (cf. De Wit et al. 2018, who reach the same conclusion).

The discussion in the literature raises the following research question.

$\begin{array}{ll}\text { Research } & \text { Is there a relation between performatives and a particular } \\ \text { question: } & \text { tense and aspect and modality, and, if so, how can this } \\ & \text { relation be explained? }\end{array}$

In this paper, I will test the following hypotheses and statements put forward in the literature by looking at the TAM of performative in 106 languages, and I will also look at other rules or regularities with respect to TAM and performatives:

1. In languages with a perfective/imperfective distinction, the imperfective is chosen for performatives (Verschueren 1995) and perfective performatives do not exist (Hewson 2012). If a language has a general imperfective construction, this construction will be chosen for performatives (De Wit et al. 2018).

2. Perfective performatives are (or are derived from) resultative constructions (Andrason 2012, Andrason 2016).

3. Past (including perfect) performatives actually refer back to an earlier act (Dekker 2018).

4. The progressive is not used in performatives (Bybee and Dahl 1989; De Wit et al. 2018). 
5. The TAM of the performative equals the TAM of the reportive present, stage directions and similar contexts of coincidence, such as the historical present (cf. Koschmieder 1930; Dahl 1985; De Wit et al. 2018).

As I will show, performatives are expressed by different kinds of tense-aspect (TA)-markings, even though there is not much variation with respect to modality. The data do not unequivocally support the claim that performatives are more inherently associated with either the imperfective or perfective aspect, even though there is a strong association between present reference and performatives (where this present reference may be expressed by various TA-categories such as a present tense, a non-tensed imperfective, a non-past, a perfective or a verb without TA-marking). Because the division of labor between tense and aspect differs from language to language, it is not possible to formulate simple and straightforward universally valid rules which predict the TA of performatives in a particular language, but it is possible to formulate crosslinguistic tendencies and regularities.

The paper has the following structure. In Section 2, I give a definition of the notion of "performative", and I discuss the notions of tense and aspect. In Section 3, I provide a brief discussion of the way in which I collected my data. In Section 4, I present an extensive overview of the various ways in which performatives are expressed crosslinguistically (Section 4.1) and I provide general rules for the use of TAM in performatives (Section 4.2). Finally, in Section 5, I present the conclusion of my paper.

\section{The notions performative, and tense, aspect and modality (TAM)}

\subsection{The notion of "performative"}

The first linguist to devote an explicit analysis to performatives is Koschmieder (1930) (called “Koinzidenzfall” by him), and Koschmieder (1945: 27-28), who provides an analysis in terms of the theory of communication of Karl Bühler. The term "performative" itself can be credited to Austin (1962). Performative utterances in the sense of Austin (1962) such as I promise are utterances that do not merely describe or report something, and which are not "true" or "false". Instead, "the uttering of the sentence is, or is part of doing an action, which would not normally be described as saying 
something” (Austin 1962: 5). In his early work, Austin makes a distinction between performatives with a performative verb (“explicit” performatives), and performatives without a verb such as Guilty! (1962: 85). The latter type of instances are not explicit performatives (1962: 32) but must be seen as “implicit” performatives or as "not pure" performatives (Austin 1962: 83). However, according to him, in the end, any performative should be reducible, expandable, or analysable into a form with a verb in the first person present indicative active (1962: 61). This means that for example directives such as Go! can be analysed as implicit performatives derivable from I order you to go (see Austin 1962: 32). This criterion, is, however, not very well applicable from a crosslinguistic perspective, and moreover, it remains unclear what "reducible" means. As has been pointed out by many scholars, by allowing for implicit performatives, the distinction between performatives and constatives becomes blurred, to such an extent that every utterance can be seen as a performative (see e.g. Dekker 2018). This difficulty also led Austin himself to give up the dichotomy of performative/constatives (Austin 1962: 149) in favor of more general families of related and overlapping speech acts. For the present study, however, I will define "performatives" in the narrower way, as such maintaining the performative/constative dichotomy (see for example Recanati 1987, for a more thorough discussion of the notion of performative):

Performative By uttering the sentence the speaker not only describes utterance:

the event expressed by the predicate, but also performs the act described by the predicate at the moment of speech.

According to this definition, performatives always indirectly perform something through a constative act. Note that this definition is not fully identical to Austin's early definition of "performative" where the constative element is lacking altogether. My definition, however, implies that a performative utterance is a declarative/assertive sentence and not, for example, an imperative with a directive force. Furthermore, in prototypical instances the grammatical subject of the verb is either a first person, or the predicate is associated with a first person logical subject (if no subject is expressed, or in the case of a subject of a passive sentence), even though, as I will show, this is not always the case.

In order to better understand the definition of performativity used here, cf. the following sentences:

(1) I congratulate you on your success!

(2) Agreed! 
(3) Your name is Dorje Namgyal. ${ }^{1}$

(4) I would like to congratulate you. [semi-performative]

(5) Congratulations! [not performative]

(6) Go! [not performative]

Sentence (1) is a performative in the strict sense since the speaker performs the act of congratulating by reporting about it. Sentence (2), containing a past participle without subject, can also be seen as an actual performative since it contains a verb which both reports about a complete event, something which is agreed, while at the same time performing the action. The same is true for (3) which does not describe the act of the speaker itself, but nevertheless has a performative character, since by uttering the sentence, a name is given through describing the situation where someone has a name. In (4) the verb congratulate occurs as the object of 'would like'. In this case, one might argue, the performative act is more implicit or indirect than in (1) since the speaker only reports about a desire to congratulate. Nevertheless, this sentence is close to an actual performative, because by expressing the desire to congratulate the act of congratulating itself is performed. Sentence (5), however, consists of no more than a noun in the plural and lacks a verb (to be interpreted as 'congratulations to you') and therefore cannot be seen as an explicit performative in the strict sense, even if the function of the utterance is very similar to (1). Many languages do have in fact have special markers for meanings that in English are expressed by a performative verb (e.g. marking for a promise in Sumerian, Jagersma 2010, or the requestive suffix in Tukang Besi; Donohue 1999: 217). Since such markings are not actual transparent verbs with the meaning 'promise' or 'ask' that can also be used in regular descriptive (constative) contexts, they cannot be seen as actual (explicit) performatives. They may, however, fulfill similar functions as performative utterances in for example English. Finally, sentence (6), which contains an imperative, cannot be seen as a performative, since it does not describe or report anything, and by using it the speaker only performs a directive act.

Besides sentences which are functionally similar to performatives, there are also constructions which show formal and semantic similarities to performatives, but which can nevertheless not be seen as actual performatives. This is for example the case with English sentences such as Hereby I send (I am sending) you this letter. This sentence is not performative since the act is not performed by uttering or writing down the sentence. The performative "flavor" is the result of the use of hereby, which seems to point the attention of the addressee to the

1 In a name giving ceremony; example taken from Garrett (2001: 141) as the translation of a Tibetan example. 
whole writing-sending act, the result of which (i.e. the letter itself) can be witnessed by the addressee. In many (often ancient) languages such constructions can be used in the past tense, called the epistolary past tense, as in example (7) from Old Novgorodian Russian, where the writer uses the perfect in a letter on birchbark even though the action has not been completed yet when the sentence is written down:
(7) Poslasmb $k$ tobě šestb bocekb vina. (Dekker 2018: 116)
send-1SG.M.PRF to you six barrels wine.GEN
Lit. '[Hereby] I have sent to you six barrels of wine.'

See Schaeken, Fortuin and Dekker (2014), and Dekker (2018) for an overview of the epistolary past tense in Russian and other languages. Instances as in (7) differ from real perfect(ive) performatives as in Spoken Yemeni Arabic like in (8), or the perfective in Siamou as in (9), where the uttering of the sentence coincides with the act expressed by the lexical verb: ${ }^{2}$

(8) kallamt-if hāðam l-kalām mā jitkarrar- $\int$
say.PFV.1SG-2SGF DEM the-words
'I forbid you to repeat these words.' (Naïm 2016: 331)

(9) $\hat{N}$ ni $\quad n \quad k a ́$.

1SG FIN 1SG refuse.PFV

'I refuse.' (Toews 2015: 220)

For this paper, I have tried as much as possible to base my conclusions on clear instances of performatives. ${ }^{3}$

\subsection{Tense and aspect (and mood)}

The concept of tense centres around the deictic grammatical category that expresses time with reference to the moment of speaking (or sometimes another

2 The glosses in this paper are adapted slightly from the glosses provided by the authors from whom I took the examples.

3 Austin (1962: 150-176) also remarks that performatives do not form one semantic or functional homogeneous category and subdivides speech acts into five specific classes, which are also used by many scholars to classify performative utterances (verdictives, exercitives, commissives, behabitives, and expositives). Searle (1975) provides a somewhat different classification which is partly based on his concept of "direction of fit". 
vantage point). In this study, I will show that performatives can be expressed by several tenses (present, past and future tense), and by verb forms that cannot be seen as belonging to one of those tenses (such as the aorist in Ewe or perfect in Wolof). The term mood is used for grammatical features of a verb that express modality (see Bybee et al. 1994: 181, for this definition of mood). Most performatives in my sample of languages do not have special marking for mood, with the exception of a few languages where (some) performatives are associated with irrealis mood or evidential mood. A central concept of this study is verbal aspect. The term (verbal) aspect is used for grammatical categories that provide a temporal perspective on events expressed by verbs, that is, how an event extends over time, and whether it is for example presented as a whole (something complete or total) or not. As such, aspect differs from tense, which has to do with the temporal relation between the event denoted by the verb and the reference point, such as the point of speech. Many authors make a principled binary distinction between perfective and imperfective aspect, where the imperfective aspect is further subdivided into habitual and continuous aspect (for example Comrie 1976). Following Comrie (1976: 12, 24-25) the term "perfective" could be defined in relation to "imperfective" and denoting a situation viewed in its entirety, without regard to its internal temporal constituency (cf. Dahl 1985: 78 for a somewhat different definition).

Even though it is relevant to provide general definitions of the perfective or imperfective or aspect to compare languages, there are considerable differences between languages with respect to these categories. Even within Indo-European we can already observe differences between the aspectual systems of various languages. One important difference is that in Slavic the perfective centres around the attainment of an inherent or imposed boundary of the event (closely connected to the presence of aspectual prefixes), whereas in the Romance languages or Greek the perfective aspect the centres around the concept of a temporally bounded event, irrespective of whether the event is telic or not. In Bulgarian we find a combination of both systems, such that one finds a perfective and imperfective imperfect, and a perfective and imperfective aorist. In the same vein, it is also possible to make a distinction between the perfective aspect and the perfect. A typical example of the perfect is perfect of result, where "a present state is referred to as being the result of some past situation" (Comrie 1976: 56) as in English I have eaten an apple (but see Dahl (1985: 231-233) for various other types of perfect). In a language like Dutch the perfect is the form that is used to refer to past events as long as it represents a retrospective viewpoint, that it summarizes an event, and detaches it from its background (de Haan 1991). This form is opposed to the past tense, which is typically used for past events in a narrative setting. From a typological perspective, the perfect 
can be distinguished from the perfective past, which expresses a completed (past) bounded event (as in Slavic) or a past event which event time is included in the reference time (as in Romance or Greek). In some languages, however, for example Russian, the same form is used both as a perfective past and to indicate a perfect use. On the other hand, in Mandarin Chinese, when the durative marker zhe is combined with verbs that indicate a movement, it indicates the resultative state of this movement (e.g. xiě 'write down'> xiě zhe 'to be written down'); something which would be expressed by a perfect construction in other languages (see Wiedenhof 2004: 202-203). More in general, if we consider nonIndo-European languages it becomes even clearer that aspectual categories differ greatly. Languages like Aleut (Bergsland 1997) or East Greenlandic (Mennecier 2016) employ aspectual differences which are difficult to classify as perfective or imperfective. For a further discussion of the status of tense and aspect, and the categories used in this paper, I refer the reader to Croft (2012), who provides an analysis of the TAM-categories found by Dahl (1985). In my view, categories such as "perfective”, “imperfective”, “perfect”, “present”, "past", etc. can best be seen as comparative concepts in the sense of Haspelmath (2010) (cf. Dahl 1985; Bybee et al. 1994; Janda 2004), which can very well be used to compare languages, even though in each case it is important to look at the specific division of labor between TA(M)-markers in the language in question.

Even though tense, aspect and modality can be defined separately, in many cases it is difficult to treat tense, aspect (and mood) separately due to the fact that in many languages there is a close but not complete correlation between tense and aspect. To give an example, in Modern Standard Arabic and Ancient Greek, the perfect(ive) and aorist respectively, have a close relation with the past tense (and the imperfective and indicative respectively with the present), but both in Modern Standard Arabic and Ancient Greek there are exceptions where a perfect(ive) or aorist refers to an event which does not lie before the moment of speech. This explains why there may be disagreement among linguists whether it must be seen as primarily a tense or aspectual category. In general most grammatical TAM categories have several uses or perhaps senses, which do not neatly follow tense or aspect. This can be clearly illustrated with the Dutch past tense form, which is also used for events that do not lie in the past but which have a "irrealis"-like status (Janssen 1994). One can argue that the Dutch past tense form has a more abstract meaning, and that the past "tense" is a conditionally conditioned use rather than a meaning, or one can argue that the basic meaning is the past tense, and the irrealis uses are peripheral senses of the verb form. Such instances show the difficulty of determining the exact status of TAM-forms. 


\section{Data collection}

Performatives have been extensively studied from the perspective of theoretical linguistics and philosophy of language, and usually focus on English. More indepth discussions of non-European languages are relatively rare. Besides the large body of literature mentioning performatives in ancient languages of the Mediterranean and the Middle East, more in-depth discussions are Jaggar (2005) on Hausa, and Andrason and Dlali (2017) on performative constructions in Xhosa (Bantu). It should be noted that the use of performatives is often quite language and culture specific. To give an example, in order to open a meeting, one has to have a cultural practice of having a meeting, which has to be opened officially. Some languages rarely use performatives. Sadock and Zwicky (1985: 156) argue for example that English is rich in explicit performative verbs, but spoken Tamil has nothing truly comparable to this construction (even though explicit performatives with 'tell' are mentioned by Brown and Levinson for Tamil). Rosaldo (1982: 215216) also remarks that in Ilongot explicit performatives are not or at least very rarely used. But in Limba (Niger-Congo) performative practices and the use of performative verbs seem to be very common (Finnegan 1969), and performatives also occur in other non-European languages such Burmese (Rattanapitak 2013), which shows that their use is certainly not a purely western phenomenon. Nevertheless, the actual pragmatic function of performatives seems to be language-dependent (see e.g. Wierzbicka 1991; Yu 2011).

In order to gain insight into the relation between performatives and TA(M) I have collected data (i.e. instances of performatives) from grammars and existing literature on performatives (including De Wit et al. 2018). Performatives are not a universal linguistic category in the sense that crosslinguistically we find special dedicated forms that are used for performatives only. Most descriptive grammars therefore only explicitly list performatives and their TA(M) if there is a specialized way of expressing a performative or if they have an inherent link with a particular tense or aspect. In order to enlarge the number of languages, and to get more information on specific details of the languages, I also looked for examples in Bible translations, and I used elicitation of native speakers or language experts, in some cases by using a questionnaire in the sense of Dahl (1985). The cultural dimension of performatives makes it difficult, however, to collect data solely by using a questionnaire. Since I have collected data from different (type of) sources, which each provide more or less information about performatives, the depth of information about performatives in the languages in my sample differs from language to language. Nevertheless, the overview provides ample insight into the typology of performatives and their TA(M). 
Although it is not my primary aim to make quantitative claims about the data, I have collected the data as much as possible from a well-balanced data set, taking families (genera) and geographical areas into account. Note that I also deliberately tried to collect various data from different languages within one family or genera in order to test whether particular uses can be contributed to these families or genera, or to particular geographical areas. Because of this Indo-European languages, Semitic languages and Bantu languages are relatively overrepresented. Appendix A below contains a linguistic classification of the languages in my sample. I refer the reader to the supplementary data (appendix B) for a sample of the 106 languages used in this paper and the way they express performatives.

Data on performatives in the languages from North America, South America and Oceania are also relatively underrepresented in grammars and linguistic descriptions, whereas for example grammars or linguistic descriptions on languages of Africa or Europe that explicitly list performatives are relatively overrepresented. In some cases, this may perhaps imply the lack of performatives (as a relevant linguistic phenomenon) in languages where performatives are not discussed, but in other instances it may mean that there is no linguistic tradition to mention performatives in the description of a grammar. Finally, since many performatives are closely connected to particular conventionalized and ritual settings, one may hypothesize that the absence of performatives in grammars of some languages (probably with the exception of expressions like 'I say/tell') may also be due to the absence of such cultural practices among the speakers of these languages, especially in pre-literate and non-urban societies.

\section{Performatives from a crosslinguistic perspective}

\subsection{Crosslinguistic overview}

As I will show below in my discussion of the use of performatives crosslinguistically and the relation to TA(M), we find the following constructions (forms):

a) Verb not marked for TA(M) (in languages without tense and grammatical aspect)

b) Simple present, imperfective present, (non-tensed) imperfective

c) Perfective present (in Slavic only)

d) Perfective past, perfect, perfective (in languages without tense) 
e) Resultative/Passive

f) Progressive

g) Future tense

h) Mood and evidentiality markers

\subsubsection{Verb not marked for TA(M)}

Some languages lack both tense and aspect (perfective imperfective) as grammatical categories. This is for example the case in Rengao (Austroasiatic), where the plain verb form is used for performatives (Gregerson 1971). In Rengao one cannot determine the tense or aspect of the verb in the case of performatives since tense and aspect are not relevant categories, even though one can indicate completion, incompletion, duration etc. by lexical means (Gregerson 1971: 67-73). There are also languages without tense, which can express aspectual notions with specialized aspectual forms. An example is Mandarin Chinese, which has four aspectual markers (le, guo, zhe, and zai). These aspectual markers are not grammaticalized in the sense that each verb is either perfective or imperfective, even though Dahl (1985: 72) lists Mandarin as a language with a perfective imperfective distinction, where the obligatory use of the imperfective occurs in a limited set of contexts. Finally, there are languages such as Kilivila, where we find a system with a plain (tenseless and aspectless) form, which is opposed to aspectual and modal forms (completive, incompletive, habitual) (see Senft 1986). It is difficult to formulate clear and objective criteria to distinguish languages without grammatical TA-marking from languages with grammatical TA-marking, and it is probably best to see this in terms of a scale ranging from clear examples (Ambel, Rengao), which lack both tense and aspect, to less clear examples, which at least sometimes obligatorily mark aspect (Kilivila or Mandarin Chinese). Whether or not Mandarin Chinese and Kilivila can be seen as languages without grammaticalized aspect, in these languages the plain verb form without any aspectual particles (perfective or imperfective) is used for performatives, probably because the aspectual markers would place too much emphasis on notions such as completion (change) or duration.

\subsubsection{Simple present, imperfective present or imperfective}

In this section I will discuss present tense performatives, and imperfective performatives in languages without tense, where the imperfective is often (though not exclusively) associated with a present event. One can distinguish various types of 
present tense performatives, depending on the aspectual structure of the language in question. In most languages, there is no perfective-imperfective marking in the present tense, but sometimes these languages have an aspectually unmarked present which stands in opposition to the present marked for habituality (for example Swahili) or the present marked for the progressive (durative) aspect, as in English. In the absence of aspectual marking these forms are usually morphologically less complex than other present tense forms and are therefore often called "simple present". This can also be illustrated with Shupamem (Bantoid), where a performative is expressed by a non-aspectually marked simple present as in (10), whereas the present progressive or present habitual is used for progressive and habitual and frequentative contexts:

(10) Mă jàß ú mà mfj̀n.

1SG name you as king

'I name you the king.' (Nchare 2012: 288)

In South Conchucos Quechua the morphologically (formally) unmarked present tense is used both for habitual and performative meanings (Hintz 2011: 80-81), but only in the case of the performative does it occur without the continuous marker (-yka:) because the event in the performative utterance has a punctual reading in which the beginning and endpoints are identical (cf. the simple present in English):
hura-Ø-:-mi
qara-na-:-pa:
$k a-q-t a$
promise-PRS-1-DIR give-NMLZ.I-1-PURP be-AG-OBJ
'I promise to give it to you.' (Hintz 2011: 80)

Not all languages that have a simple present which is opposed to other present tense forms use this form for performatives, in spite of seeming suitability for this function. This is because in some languages the simple present has a rather limited usage. This is for example the case in Lucazi (Bantu) (Fleisch 2000: 145), where the so-called basic present is primarily used to express gnomic statements, and in Chichewa where the simple present seems to disappear from the linguistic structure (see examples (34)-(35)). This may in fact be part of a more general tendency in language. One can hypothesize that in order to express a particular meaning, language users will prefer to use the morphologically marked (and longer) form in order to make sure that the meaning will be expressed clearly. This means that the non-marked form will be used for more specialized and not necessarily frequently used functions (as such implying that the principle that more frequently used forms are morphologically simpler is 
overruled here). This clearly differs, however, from the simple present in languages like English (Leech 1971, and Binnick 1991: 247), where it has a larger array of uses (e.g. in English: futurate, historical, stative, frequentative, reportive, indefinite, gnomic, descriptive, performative). Langacker (2001: 27) provides an analysis of the performative use of the English simple present in terms of coincidence between the speech event, which is controlled by the speaker, and the event denoted by the verb. Such an explanation can possibly also be given for a language like South Conchucos Quechua.

In languages like Shupamem or Quechua the simple present is clearly opposed to other present tense forms, and lacks morphological aspectual marking, but there are also many languages where there is only one aspectually nonmarked present tense form, which only stands in opposition to more specialized present tense forms. This is for example the case in French or Dutch, where we find the present tense alongside the periphrastic progressive construction. For such languages the term "simple present" is not really suitable, and I prefer to use the term "general present" or just "present". Besides languages which have a simple present or aspectually non-marked general present, we find languages where the performative is expressed by an imperfective present, which is also used in the case of progressive (durative) contexts or habitual contexts. This is for example the case in Russian, where performatives are expressed by the imperfective present tense (imperfective marking and present marking). In Russian, the imperfective present is opposed to the perfective present and functions as a general present (see Section 4.1.3 for more discussion). A similar situation can be found Lezgian, where we find the imperfective present in performatives:

Za har-da sa ttar wa?, q'we ttar ak'ur-un
I:ERG [every-SBST.SG(ERG)
teklif-zawa.
propose-IPFV

'I propose that everyone plant not one, but two trees.' (Haspelmath 1993: 140)

The imperfective is used in Lezgian for progressive situations or states that obtain at the time of reference such as habitual situations (Haspelmath 1993: 140). Without tense marking the imperfective always refers to a present situation, as opposed to the past imperfective, which expresses a past progressive or habitual situation. As such the imperfective can be seen as a general present tense form.

In my sample, languages that have a general present use this form without exception to express performatives. Aspectually non-marked presents are very 
suitable to express performatives because they can express coincidence or overlap between the speech event and the event expressed by the performative verb, without focusing on the internal structure of the event, as would be the case if the progressive were used. The same function can also occur in languages with an imperfective present such as Russian, where the imperfective present is used as a general present tense form, which does not necessarily focus on the duration of an event. In my sample there are also quite a few language which lack tense as a grammatical category, but which have a grammaticalized perfective imperfective distinction (for the Semitic languages sometimes called perfect imperfect, and for many languages in America completive incompletive), for example Akkadian, Biblical Hebrew, Modern Standard Arabic, Tarifiyt (Berber), Hausa, Tigrinya, Tzotzil and Yukaghir. In this class we see quite a lot of variation. In Tarifiyt the imperfective is often used in performatives, but the perfective is used with some verbs in some contexts. In Hausa, on the other hand, the perfective (completive) seems to be more common, and in Akkadian and Biblical Hebrew we only find the preterite (perfective past) and perfect(ive) respectively. In Badiaranke, Yukaghir and Tigrinya, however, the imperfective seems to be the only possible choice in performatives. See Section 4.1.4 for an extensive discussion of the use of perfective performatives. In the case of the imperfective the idea of reference to the present (i.e. coincidence or overlap between the moment of speech and the event referred to by the verb) is not expressed by the form-meaning element itself, but an interpretation or sense of the verb-form.

\subsubsection{Perfective present}

The term "perfective present" (or "present perfective") is difficult to define in a crosslinguistic manner, even though it is often used to refer to a form morphologically marked for the present tense and the perfective aspect irrespective of whether it has present tense semantics (cf. De Wit 2017 for a discussion of the "present perfective" across languages). This is for example the case with the Slavic perfective present. Whereas in some Slavic languages, for example Russian, the main function of the perfective present is to express futurity (of a terminative event), in other Slavic languages the perfective present can also be used in the case of the historical present or stage directions (Czech, Slovene), and in Slovene and Bulgarian the perfective present is not used as a perfective future tense form. The situation in Slavic differs from that of modern Greek, where the present marked for the perfective functions as a subjunctive in dependent clauses (Holton et al. 1997), and we also find a subjunctive-like 
function of the perfective present in Pashto (Indo-Iranian), which expresses modality in independent clauses and potential actions in dependent clauses (David and Goodman 2013). In this case the term "perfective present" is less suitable to refer to the semantics of the form. Another instance of the perfective present can be found in Kirundi (Bantu). As mentioned by De Wit et al. (2018) in Kirundi, performatives are marked with the perfective present, which consists of the $\varnothing$-prefix, which indicates a present, and the -ye suffix, which indicates the perfective. It should be noted, though, that the perfective present form is typically used to indicate an event that is situated in the recent past, close to the moment of speaking, for example a-ci-ye héehé? (SC3SG-pass-PFV where; 'He just passed where?'). ${ }^{4}$ A similar function of expressing an immediate past can be found in the case of the present perfective in the Bantu language Lucazi (Fleisch 2000: 162-163, 256-257, 278), and in Wampis (Peña 2015), a language spoken in Peru. One could argue that in both Kirundi and Lucazi the perfective present is used in performatives since they express events that are already realized as soon as the sentence is spoken, but it should be noted that the present perfective is not used in performatives in Wampis. I will discuss this issue further in Section 4.1.4, and Section 4.2.

De Wit et al. (2018) also mention Lingala (Bantu) as a language which employs the present perfective in performatives, but this form can also refer to a past event, as is clear from the discussion by Brisard and Meeuwis, who use the term "present perfect". The present perfect in Lingala seems to behave like a factative in the sense of Welmers (1973: 346-347), which is common in western Africa. Welmers calls such tenses "factative" since they report about the fact that the active (dynamic) verb was observed or took place, but that the stative verb obtains at present. Typical for factatives is that the same form is used for past completed (non-continuous) events and for states, which are conceptualized as resultative states of completed events. Most of the notions encoded as stative verbs in other languages are actually expressed as inchoative verbs in languages with a factative. The term "factative" can further be illustrated with the so-called "perfect" in Wolof. In his extensive discussion of Wolof, Robert (2016: 194) argues that the perfect indicates "that a process already known to be ongoing has henceforth reached its expected end-point or term, so that there is nothing to add, no further variation: a stable resulting state has been reached at the time of speech." The perfect does not necessarily refer to a past event, but the temporal interpretation depends on the Aktionsart of the verb but also on contextual clues, such that the verb bañ ('refuse') with a perfect marker can be interpreted as referring to the present as in (13), where it gets the stative

4 Ferdinand Mberamihigo (pc). 
meaning 'hate', or to the past as in (14), where it has the dynamic meaning 'refuse':

(13) Bañ na ma.

refuse PRF.3SG OPR.1SG

'He hates (has refused) me.' (Robert 2016: 189)

(14) Bañ na ko.

refuse PRF.3SG OPR.3SG

'He refused it (his proposal).' (Robert 2016: 189)

Similarly, in Tarifiyt (Berber), the perfective is also interpreted as referring to the past in dynamic verbs, and to the present or the past with stative verbs. As such, the Tarifiyt perfective shares similarities with these West African languages, but also partly with a language like Hausa, where the completive (perfective) can also be used to refer to present context events with stative verbs.

I have shown that across languages a perfective present construction can refer to an immediate past, present, future, modal event or that it can have a broader temporal reference (for example referring to an immediate past or present event; cf. also Comrie 1985: 92). We also find languages where a perfective present is not grammatically acceptable at all. An example is Khoekhoe, where we find the present tense (zero marking), and the punctual aspect (zero marking), which can be seen as a perfective aspect. In Khoekhoe the punctual aspect cannot be combined, however, with the present, since such as sentence 'would describe an event whose happening is exactly coterminous with the point in time at which the sentence is uttered (...) [which is] an extremely unlikely occurrence.' (Hagman 1973: 125). However, as I remarked above, the very same explanation in terms of full coincidence between the event and speech act is given by Langacker (2001) for the acceptability of the simple present in performatives in English. According to Langacker such performative uses of the simple present are instances of the "present tense perfective", which occurs with dynamic verbs in performative (and reportive) contexts (cf. De Wit et al. 2018: 248). In the absence of morphological perfective marking in English, I prefer to speak about a perfective interpretation or use rather than a perfective meaning in such cases. But apart from that, the comparison between English and Khoekhoe with respect to "perfective" present performatives also shows that an explanation of the data has to refer to the larger structure in which a formmeaning element occurs. Whereas in the case of English the simple present is only opposed to the present progressive, in Khoekhoe present reference can be expressed by several forms (imperfective present, the perfective (non-punctual) 
present and the stative), which leads to a different division of labor within the linguistic structure.

In the remainder of this section, I will focus on the data from Slavic. The use of the perfective present in performative utterances is well-described for Slavic languages. As is shown in the literature (e.g. Hinrichs 1985, Hinrichs 1986; Dickey 2000; Kamphuis 2012; Derganc 2012; Wiemer 2014; Dickey 2015) across Slavic, both the (imperfective) present tense and the perfective present tense is found in performatives. According to Greenberg (2006) in Slovene performatives normally occur with the perfective present, e.g. Prisežem, da govorim resnico. 'I swear (PFV) I am telling the truth'. In his opinion, the use of the imperfective present (in this case prisegam; 'I swear-IPFV') is more typical for official or quasi-official acts. Žagar (2003, 2011), however, remarks that whereas in the case of verbs like 'promise' both aspects can be used, with other verbs, for example 'order' 'declare', only the imperfective can be used. The situation in Russian is rather different from Slovene. In Russian, the use of the perfective present is much more restricted than in Slovene and occurs mainly with verba dicendi such as 'say', 'remark' and with the verb poprosit' 'ask', whereas the imperfective present is the standard aspect in most other contexts (see Ivanov 2014 for an overview). In the case of verbs like 'remark' the actual content of the act is expressed by the subordinate clause, which may suggest that the perfective present has a weakened future tense meaning in such contexts (see also Klimonov and Klimonov 2008: 165-166). In this case the factor of politeness may also play a part, which is suggested by the use of performative constructions with modal verbs and verba dicendi in several European languages (e.g. I would like to remark that). By presenting the performative as something that might happen if the desire of the speaker were fulfilled, the performative act is mitigated (see also Section 4.1.8, for a discussion of similar constructions in other languages). See also Slavkova (2014) and Łaziński (2014) for an analysis.

The variation we find in Slavic partly follows the general typology of aspect in Slavic, where in the so-called eastern aspectual Slavic languages the perfective is not compatible with contexts where the terminative event fully coincides with the reference point (historical present, where the narrator reports about narrative events as if they happen right before his eyes, and stage directions, where the actions are described of a personage in a play), whereas in the western aspectual languages, these contexts are (more often than not) compatible with the perfective present as is shown in Table 1 (see Dickey 2000 for a discussion; Stunová 1994, for the historical present in Czech as compared to Russian). In general, Russian and Slovene seem to constitute the most extremes sides of this scale, whereas Czech is closer to Slovene, and Polish and probably Bulgarian are closer to Russian. 
Table 1: Overview of performatives in Slavic.

\begin{tabular}{|c|c|c|c|}
\hline & Performative & Historical present & Stage directions \\
\hline Slovene & $\begin{array}{l}\text { Perfective present and imperfective } \\
\text { present }\end{array}$ & $\begin{array}{l}\text { Perfective present } \\
\text { Imperfective } \\
\text { present }\end{array}$ & $\begin{array}{l}\text { Perfective present } \\
\text { (Imperfective } \\
\text { present) }\end{array}$ \\
\hline Czech & $\begin{array}{l}\text { Mostly imperfective present (exception } \\
\text { verba dicendi and some other verbs such } \\
\text { as those listed by Wiemer 2014) }\end{array}$ & $\begin{array}{l}\text { Perfective present } \\
\text { imperfective } \\
\text { present }\end{array}$ & $\begin{array}{l}\text { Perfective present } \\
\text { (Imperfective } \\
\text { present) }\end{array}$ \\
\hline Polish & $\begin{array}{l}\text { Mostly imperfective present (and } \\
\text { perfective present with limited set of } \\
\text { verbs) }\end{array}$ & $\begin{array}{l}\text { Imperfective } \\
\text { present }\end{array}$ & $\begin{array}{l}\text { Imperfective } \\
\text { present }\end{array}$ \\
\hline Bulgarian & $\begin{array}{l}\text { Imperfective present (with some verbs } \\
\text { perfective future/ imperfective future) }\end{array}$ & $\begin{array}{l}\text { Imperfective } \\
\text { present }\end{array}$ & $\begin{array}{l}\text { Imperfective } \\
\text { present }\end{array}$ \\
\hline Russian & $\begin{array}{l}\text { Imperfective present (exception verba } \\
\text { dicendi) }\end{array}$ & $\begin{array}{l}\text { Imperfective } \\
\text { present }\end{array}$ & $\begin{array}{l}\text { Imperfective } \\
\text { present }\end{array}$ \\
\hline
\end{tabular}

The data suggest that those Slavic languages where the perfective merely expresses "totality" (i.e. a complete bounded (terminative) event), the performative is often (depending on the lexical verb) possible with the perfective present, because of the inherent bounded character of performatives, where the event is completed as soon as the utterance is finished. This is even clearer in Slovene than in Czech, possibly because only in Slovene, the perfective present is not used as a dedicated future tense marker, whereas in Czech the possible future orientation blocks the perfective present in many performative contexts. The use of perfective present performatives is almost absent in Russian, where the perfective is automatically interpreted as a future event (relative to the moment of speech), which is less in accordance with the function of performatives. Dickey (2000) argues that the data from Slavic can be explained with reference to the semantics of the perfective (and imperfective) aspect, which in Russian (and Bulgarian) has the additional meaning feature of "temporal definiteness" or "sequential connection". This feature requires that the meaning of totality in Russian and Bulgarian is further sustained by the context, which emphasizes this totality by linking the event to some prior or subsequent situation (see also Fortuin and Kamphuis 2015, 2018 for further discussion). Dickey's (2000: 186) explanation essentially boils down to the idea that it is cognitively already rather difficult to identify a situation as a totality quickly enough to express it verbally simultaneous to its occurrence. As such it must certainly be even more difficult to identify it not only as total but also uniquely located in time relative to prior and subsequent situations quickly enough to express it verbally 
simultaneous to its occurrence. Alternatively, one might say that it is not clear what this prior or subsequent situation would be in the case of performatives other than the moment of speech itself. However, as soon as the performative situation is linked to the moment of speech, this results in a future tense meaning. ${ }^{5}$

\subsection{4 (Perfective) past tense, perfective, and perfect}

In this section I will discuss instances of the performative with a (perfective) past or perfective. These categories all have in common that they denote an event presented as completed before the moment of speech, or, in the case of the nontensed perfective, present the event as complete (total). In addition to that, I discuss perfects, which can refer to a present state that is the result of the completion of an event. Because of this they share similarities with the present tense, and are marked by a present tense form in some languages, for example in English (e.g. I have given).

The use of a perfective (often called "perfect") for performatives is especially well-known from the study of Ancient Semitic languages of the Near East such as Ancient Egyptian, Biblical Hebrew, Biblical Aramaic, Ugaritic, and Ge'ez. In Akkadian we find the preterite (perfective past tense) in performatives. I refer the reader to Hassellbach-Andee (2015) for a very complete overview of the data and references. The use of the perfective can also be found in other ancient nonSemitic languages, such as Ancient (Attic) Greek, which uses the aorist (primarily a past tense form), besides the present tense (Bary 2009: 214), and in early Vedic performatives could be expressed by the aorist indicative (in pragmatically marked contexts) and the aorist injunctive (E. Dahl 2008, Dahl 2010) besides the present. According to E. Dahl (2010) the aorist injunctive denotes the general perfective aspect and does not exclusively refer to past events. Finally, perfect and aorist performatives also occur in Old (Novgorodian) Russian (see for example Schaeken, Fortuin and Dekker 2014; Dekker 2018).

5 Dickey (2015: 297) puts forward the hypothesis that German language influence preserved the older use of the perfective present in performatives in the western Slavic languages, and apparently more so in Slovene than in Czech. Note, however, that Michałk (1959: 243) remarks that in Sorbian the perfective present is often used in performatives and stage directions in the "unbeeinflusste Volkssprache" suggesting that German influence triggered the loss of the perfective present in performatives. This issue needs further research (cf. also Kamphuis 2012; Fortuin \& Kamphuis 2018). 
In modern Afroasiatic languages the use of the perfect(ive) besides the present tense or imperfect is found in Classical Arabic, Modern Standard Arabic (Mughazy 2011; Marmorstein 2016, Marmorstein 2018; Abboud and McCarus 1983: 289) and various varieties of colloquial Arabic (Cuvalay-Haak 1997: 134; Bergman 2005: 28; Naïm 2016: 331; Rubin 2018: 164). The use of the perfect(ive) can also be found in other Afro-Asiatic languages such as Tarifiyt (Berber) (Khalid Mourigh (pc)), Hausa (Jaggar 2006: 111), and Amharic (Manahlot 1988). In my sample, perfective performatives are also found in some Bantu (Bantoid) languages (Lingala, Lucazi, Kirundi, Luganda), in some Atlantic-Congo languages (Wolof, Ewe, Kom and Siamou), and in the Songhay language Zarma. Some of these languages of western Africa constitute a separate category with respect to the use of the perfect(ive) with performatives since the perfect(ive) behaves like a factative, as I discussed in Section 4.1.3. This is for example the case in Ewe, Wolof and Lingala.

In the vicinity of the Middle East, perfect performatives can be found in Georgian (Friedman 1979: 342):

\section{(15) Mo-m-i-loc-av-s!}

PREV-I-OV-congratulate-PRF-it

'Congratulations'! (lit. 'I have congratulated (blessed) you!') (Hewitt 1995: 260)

This use is limited to specific lexical verbs and the standard form in performatives is the present tense. The use of (perfective) simple past tense performatives is also mentioned for Tajik Persian by Perry (2005: 214), who provides the example Turo baxšidam! (you.Acc forgive.1SG.PST) 'I forgive you.' Since in other contexts, Tajik Persian seems to use the present tense, the use of the past tense is probably related to the specific context of use of this sentence, where the speaker performs an act by saying that he has already forgiven someone (cf. You are forgiven/I have forgiven you). In Central Asia past tense performatives are also mentioned for colloquial Mongolian by Svantesson (1991: 192), who provides an example with the suffix -(ว)w which expresses a stylistically marked (plain) past (where gež seems to function as a topic indicator for 'Bat'):

(16) bi: en xu:xd-ig bat ge-ž nerl-əw.

I this child-ACC Bat say-PROG name-PST

'I name this child Bat.'

According to Binnick (2012: 93) $-w$ must be seen as the counterpart of the past perfect (-lee) in the spoken language, which expresses an immediate past or 
evidential past. And indeed, Brosig (2018: 66) also presents a performative example with -lee, called direct past by him.

Outside of Europe, Africa, the Middle East and Central Asia, the use of perfective performatives can be found in a few languages in America. In Totonac the perfective without additional tense marking can be used in performatives (Beck 2011: 377), and in the northern Iroquoian languages performatives are expressed by the aorist and the punctual aspect (Foster 1986: 70). For Mohawk, the aorist is also called "factual" by some grammarians since it indicates that the action has taken place in the real world:

\section{(17) Sak wa'-ku-hsvn-u-’.}

Sak FACT-1sS/2sO-name-give-PUNC

'I (hereby) give you the name Sak.' (Baker and Travis 1997: 217)

Another interesting use can be found in Colonial Valley Zapotec (17th, 18th century) where the so-called "perfect" could be used in performatives combined with the (habitual) present (Broadwell (pc)):
naa hua-ti-caabi $=\mathbf{l i j}=a$
çòo
eezij $=a$
I PERF-HAB-promise $=\mathrm{EMPH}=1 \mathrm{SG}$ be.standing improve $=1 \mathrm{SG}$
'I promise to improve' (Aguero 1666; Aaron Broadwell pc)

In other contexts, the combination of the so-called "perfect" and the (habitual) present expresses 'has always X' or 'has X-ed many times', but in this context it may be that the perfect expresses that the event has "already" been performed. I have not found similar uses of the perfective or perfect in other languages of America (Southern Iroquoian (i.e. Cherokee), Aleut, Purépecha, Tzotztil, Mixtec, Shiwiar), even though a possible exception is Karuk, a language of California, where the perfective is possibly used in performatives (see Carpenter 2014).

Finally, we find the use of a perfective in my sample in Mian, a Papuan language from New Guinea. In Mian performatives can be expressed by the realis with perfective marking, which is normally used to express immediate past (Fedden 2011: 246, 291):

(19) klayâm $=0=b o$

really_good $=\mathrm{PRD}=\mathrm{QUOT}$

ge baa-` b'-ke- $\boldsymbol{\emptyset}$-i-o=be

say.PFV say.PFV-give.PFV-2SG.R-REAL-1SG.SBJ-EP=DECL

'I thank you.' (lit. 'I say to you: “Really good.”') (Fedden 2011: 291) 
How can the use of perfective performatives be explained? A very common explanation is that the performative act itself must be seen as a momentaneous bounded event which is complete as soon as the sentence is uttered (see for example Werning (2008: 277) for the use of the perfect in Ancient Egyptian). A somewhat similar explanation is given by Cuvalay-Haak (1997: 134) for the use of the perfective in colloquial Arabic in terms of the perfective meaning 'I am hereby in the state of having sold you this. ${ }^{6}$ A similar explanation can be given for languages with a perfect(ive) such as the perfective in Tarifiyt, the aorist in Ewe or the present perfect in performatives in Lingala (see Brisard and Meeuwis 2009: 23), which show properties of what Welmers calls "factative" and Hewson "Performative". In such languages the temporal interpretation of the perfect(ive) depends on the interpretation of the event as stative or dynamic, and since performative verbs are typically telic, this suggests that a perfective performative situates the event (just) before the moment of speech. As such, both the perfect (ive) and the (perfective) past provide a possible construal of a performative verb in the performative speech act. Even though this explanation seems valid as such, in many languages with a perfect or perfective past, performatives are not expressed by these forms (e.g. English, French, Russian, Turkish, Greek (Modern), Hindi, Punjabi, Turkish, etc.). As such we need an extra explanatory factor to explain the past tense of a perfect(ive) performative. This factor is the division of labor with the other tense forms which may be more or less suitable to express a performative. For example, in English the aspectually and morphologically "unmarked" simple present seems to be a better candidate to express performatives, at least in most contexts, than the perfect or the progressive. In Lucazi (Bantu) as described by Fleisch (2000), however, the simple (basic) present is restricted to gnomic statements, and the other present tense forms (progressive and habitual) are not suitable to be used in performatives. Because of this the present perfective, which can be seen as an expression of "immediate past" is a more optimal candidate. Similarly, in Kirundi, the perfective present (recent past, immediate future, state as the result of a completed event) as in (20a) is used in performatives, and the use of the imperfective with a potential marker as in (20b) has the effect of an act that will be realized in the near future if particular conditions are met (Nkurikiye 1991: 165), whereas the use of the imperfective without this marker in (20c) either expresses a habitual event or a near future event (See Mberamihigo 2014 for an analysis of the potential marker):

6 Cuvalay-Haak (1997: 134) also points at the possibility that the perfective performative is linked to the factual meaning of the perfective ('I am hereby definitely selling you this.') (cf. Sxaken et al. 2014, for a similar analysis of the epistolary past tense). 
(20) a. ndayikugabiye (Nkurikiye 1991: 165)

$n$-ra-i-ku-gab-ir-ye

SC1.SG-DISJ(or FOC)-OC9-OC2SG-betroth-APPL-PFV

'I betroth it (the cow) to you'.

b. noyikugabira (ibid.)

n-oo-i-ku-gab-ir-a

SC1.SG-POT-OC9-OC2.SG-betroth-APPL-IPFV

'I would betroth it to you.'

c. ndayikugabira (Mberamihigo (pc))

n-ra-i-ku-gab-ir-a

SC1.SG-EP-OC9-OC2SG-betroth-APPL-IPFV

'I (will) betroth it to you.'

??'I habitually betroth it to you.' (pragmatically excluded)

In any case, the division of labor between the perfective and imperfective is such that the perfective is a more optimal candidate for actual performatives than the imperfective. This optimality may also have a cultural dimension, since by using a perfective form, the speaker makes clear that the performative is sincere and actually fulfilled, whereas this would not be the case if the imperfective would be used, but this cultural factor can only come into play because of the language structure.

My data show that the use of perfective performatives occurs almost exclusively in languages where the perfective has no or no exclusive past time reference, as was already suggested by Dahl (1985: 81). To illustrate this with an example, in the Romance languages there are no perfective performatives, and instead the present tense is used. In these languages the perfective clearly has an exclusive past tense meaning. This differs from those languages that have a perfective performative. This is the most evident in the case of languages which have a western African style "factative" system such as Wolof, Ewe and Berber, where the time reference of the verb depends on the dynamicity of the verb. But also in Modern Standard Arabic, for example, the perfect(ive) is not exclusively associated with past events but can be used to refer to a present event, for example in sentences which indicate gnomic time, or which have an omnitemporal character (for example in sentences with 'whenever'), and to indicate a future event (Bahloul 2008: 64, 68). ${ }^{7}$ In the same vein in Mohawk

7 De Wit et al. (2018) hypothesize that the performative use of the perfect (perfective) in Modern Standard Arabic is a remnant of Classical Arabic, suggesting that its use is somehow at odds with the modern verbal system. This might be in line with the development of an aspect-based system into a tense-based system as described by Hassellbach-Andee (2015). It should be noted, 
and other northern Iroquoian languages, the aorist marker wa'- can also be used in some (more limited) cases where it refers to events present at the moment of speech (see Baker and Travis 1997; Abbott 1981), and the aorist in Ancient Greek was used in several contexts besides the performative where it has present reference; see for example the example of the "tragic aorist" discussed by Smyth (1920); see also example (22c). On the basis of this loose time reference, Hassellbach-Andee (2015) proposes for the Semitic languages that the explanation of perfective performatives should not be based on their past character at all and should focus entirely on their aspectual property of expressing an instantaneous or punctual event which fully coincides with the moment of speech. It should be noted, though, that in languages which have a perfective "factative style" performative such as Berber, Ewe and Wolof, the perfective form suggests a past interpretation with dynamic events. This implies that performatives, which are expressed by verbs referring to dynamic events, should have a past time reference. Similarly, in many languages which employ a perfective performative the same form is used for a recent or immediate past (Kirundi, Luganda, Lucazi, Mian, Totonac). In my view, a speaker using such a form may very well be said to express both the idea of totality and the idea of completion at the moment of speech, implying that when the sentence is uttered the action is completed (i.e. past). This is also suggested by Amharic (Manahlot 1988: 626), where the imperfective, instead of the perfective seems to be used of the action has relevance past the moment of speech (e.g. in the case of 'beg'), whereas the perfective is used in contexts where in the mind of the speaker the action has already been completed before the sentence is uttered (e.g. in the case of 'decide'). Note that this use of the perfective in performatives differs from the use of the performative perfective present in Slavic. In Slavic the perfective present has no past time reference, and either refers to a future event or to an event that fully coincides with the moment of speech.

Dahl (1985: 81) suggests that those languages that use the perfective in reportives, are the same languages that use the perfective in performatives, exactly because of the loose time reference of the perfective in these languages. The term "reportive present" is used by Dahl for contexts where the speaker describes (reports) consecutive (telic) events that are happening right before his or her eyes. In many of the languages from Dahl's sample we find a perfective past tense form in such cases (see Dahl 1985: 71-72), even though the verb refers to a present event. Examples of such past tense reportives are given below for Slovene, which use a (perfective) past tense in the reportive context provided by

however, that in Modern Standard Arabic the perfect still does not necessarily refer to a present event. 
Dahl (note that the first sentence is not a reportive, but sets the scene for the dynamic events that occur after it):

(21) Fant in dekle se igrata na ulici.

boy.NOM and girl.NOM REFL play.PRS.IPFV on street

Pravkar/zdajle je fant vzel žogo in

now COP boy.NOM take.PST.PFV ball.ACC and

jo vrgel dekletu.

she.ACC throw.PST.PFV girl.DAT

Dekle jo je vrglo nazaj.

girl.NOM she.ACC COP throw.PST.PFV back

'A boy and a girl are playing in the street. Right now the boy takes a ball and throws it to the girl. The girl throws it back.'

The past perfective past is chosen because in a situation where things are happening right after the other the moment one reports about what one sees, the action is already realized. In such contexts the use of the present tense is often not fully suitable because it requires that the action has some duration. We find a similar situation in Japanese (Soga 1983: 15, 57 and further), where the perfective may refer to a past event, a present state (sometimes with a perfectlike character) or to the future. As is mentioned by Soga (1983: 57) the Japanese perfective with - $t a$ is used even if the event occurred just seconds before its completion at the moment of speech. Because of this it is used in sport broadcasts and is similar to the English present perfect tense for "hot news". In all of these cases the perfective past or the perfective has a past reference. Appendix D (see the supplementary data) lists those languages which either have a perfective performative or a perfective reportive present. The data from my sample show that even though there is an association between the TA(M) of performatives and that of reportives, reportive uses are more easily associated with a perfective than performatives (the only exception seems to be modern standard Arabic). The reason why performatives are less easily expressed by a perfective than reportives is probably that the narrative-like reportive context, where one event occurs after another in a chain of events, more easily triggers a perfective (past) than the single act of the performative. In addition to that, in the case of the reportive context, the speaker acts as a conceptualizor of events with actors (subjects) other than himself, whereas in the case of performatives the speaker is in control as actor (subject) of the event. Especially when the events quickly follow one another, the focus may be more easily be on recent completion, than in the case of the performative (see also Dickey (2000: 173) for Slavic sport reports). 
De Wit et al. (2018: 261) put forward a hypothesis which is even stronger than that of Dahl, stating that "performatives generally select that aspectual construction that is also used for the expression of other types of fully and instantly identifiable situations, namely present time states, habituals, generic situations, recipes, demonstrations, instructions, predictable (scheduled) future events and realis conditionals." This hypothesis predicts that those languages which use a perfective performative generally use the perfective much more broadly to refer to present events for example for habitual events and states. It remains to be seen whether it is possible to validate the claim that there is a universally given class of "fully and instantly identifiable situations", and it also remains to be seen whether the situations mentioned by De Wit et al. are all equally good examples of this category. Besides that, many languages have a separate habitual form which expresses habitual events, which is not used as a general marker for present time states (cf. their remark about habituals in Luganda in their 2017 paper).

I will conclude this section by discussing (and rejecting) two more hypotheses that are put forward in the literature to explain perfective performatives, namely (i) the performative use of the perfect(ive) is a remnant of an older resultative use, (ii) the performative use of the perfect(ive) is due to the older practice of referring back to a previous oral act.

The first hypothesis is advocated by Andrason (2012) for the Biblical Hebrew perfective (qatal) and presented as widely applicable to other languages with perfective (past) performatives. Andrason (2012) explains the performative use of the qatal in Biblical Hebrew in terms of the general diachronic development of resultative meanings into perfect and eventually (perfective) past meanings, the so called "anterior path cline". In languages where we find past performatives, these perfectives must be seen as remnants of an older stage of the language where the past still had a resultative meaning. Since performatives are often used in ritualized settings, it is perhaps understandable that they are retained in more or less petrified expressions. It is in fact commonly accepted that the Hebrew qatal originated from a passive adjectival participle which was reanalysed as an active verbal construction with a perfect(ive) meaning. However, in the oldest attested version of Semitic, Akkadian, the perfective past tense (iprus) is also used for performatives, even though there is no evidence that this past tense form is related to a resultative, and has no resultative uses (cf. Mayer 1976: 192ff., Mayer 1992: 397f.). Furthermore, there are other "odd" uses of the qatal such as the gnomic use or the durative use which can probably not be explained in the same way (but see Rogland (2003: 18) for the gnomic qatal). To give another example, in Biblical Hebrew the qatal of 'know' $(y d)$ refers to a present situation. One could argue that this is because of the resultative origin of the 
qatal form. At the same time, it must be remarked that in other languages the perfective past can also be used to indicate a resultative state with verbs of knowing, understanding, etc. (e.g. Tajik Persian, Russian, Ancient Greek, Hausa). In such sentences the perfective past tense indicates the result of getting into the state of not-knowing or not-understanding into the state of knowing or understanding, for example:

(22) a. Fahmidam. (Tajik Persian; Perry 2005: 214)

understand.1SG.PST.PFV

'I understand'

b. Ponjal. (Russian)

understand.1SG.PST.PFV

'I understand.'

c. xynēka (Ancient Greek; Smyth 1920 section $1937^{8}$ )

understand.1SG.PST.PFV

'I understand.'

d. mun gaanèe (Jaggar 2006: 111)

1PL.PFV understand

'We understand.'

For these languages, there is no indication that this use is a remnant of an older resultative use. This raises the question whether it is really necessary to explain the uses of the qatal or similar perfect performatives in modern languages in terms of remnants of an older meaning.

The second hypothesis is put forward by Dekker (2018: 137-176) for Old (Novgorodian) Russian and the Semitic languages. It is very striking that the perfective past tense performatives are wide-spread among the Ancient languages of the Mediterranean, both Indo-European (Ancient Greek, Vedic) and Afro-Asiatic (Akkadian, Biblical Hebrew, Egyptian, Ge'ez), and that in modern versions of the language the use of the perfective performative is absent (modern Greek) or less prevalent (Amharic, MS Arabic; see e.g. Dekker (2018: 153)). The hypothesis is that in (emerging) script cultures, where there is still a relation between the oral and the written utterance, and where the written text may be written down by a scribe, the perfective past tense or perfect tense is used to refer back to an earlier oral utterance (i.e. it is a "assertive declaration" in the sense of Searle).

8 http://www.perseus.tufts.edu/hopper/text?doc=Perseus\%3Atext\%3A1999.04.0007\%3Apart\% 3D4\%3Achapter\%3D44\%3Asection\%3D111\%3Asubsection\%3D124 
Possible evidence in favor of this hypothesis is given by Höfler (to appear), who states that in Latin the perfect could be used as a performative for example in sentences where it was used to confirm a transaction or in spepondi ('I have pledged.'), even though its use at some point became archaic. One could hypothesize that, like in Russian and Greek, the past or perfect performative use disappeared as soon as the link with an oral act was lost as well. However, I have not found such uses in other ancient script cultures of Indian America (Classic Maya) or East and South East Asia, with the exception of India (Vedic). It would also be interesting to find out whether perfective performatives occur in Sumerian, which is an ancient non-Semitic and non-Indo-European language of the Middle East, which has a perfective imperfective aspectual system. The most convincing performative case from Sumerian is, however, in the perfective (and not a first person), which can be read either as an actual (third person) past tense, or as a resultative-like, passive-like construction without subject (as discussed in the next section), and is as such inconclusive with respect to the script-hypothesis (Bram Jagersma, pc):

(23) igi $\{d\}$ utu-še3 šu u4-bi-ta e-ra-an-gi4

igi $u t u=a k=s ̌ e \quad s ̌ u \quad u 4 . b i \cdot t a=a k$

eye $\mathrm{Utu}=\mathrm{GEN}=\mathrm{TERM}$ hand before $=\mathrm{GEN}$

i-ra-n-gi4

VP-2SG.IO-3SG.A(or: 'in')-return.PFV

lit. 'Before Utu, he returned the hand of before to you. Or 'Before Utu, the hand of before was returned to you in this.'

Usual translation: 'Before Utu, your former kindness is hereby repaid to you.'9

Another interesting case is Hittite, an ancient Indo-European language. The data from Hittite seem to suggest that performatives are in the present (imperfective) tense, and not in the past tense. The Hittite data can possibly be seen as counterevidence against a cultural (script) explanation of performatives, and in favour of an explanation in terms of the aspectual system of the language since Hittite lacks a perfect(ive) imperfect(ive) structure as we find in the Semitic languages. I therefore conclude that (with the exception of Old Russian and possibly Latin) the occurrence of perfective (past tense) or perfect performatives can be explained in terms of their aspectual-temporal meaning, which expresses an event as complete and therefore completed (i.e. performed) the moment the sentence is finished.

9 Electronic Text Corpus of Sumerian Literature (text 1.8.1.1 line 112). 


\subsubsection{Resultatives - passive constructions}

Nedjalkov et al. (1988) define resultatives as forms which express states which presuppose a preceding event. As they point out, this definition is very close to that of perfects, but unlike perfects, resultatives can be combined with temporal qualifiers. More generally, in the case of resultatives, the focus is more on the state than on the event, such that they can be combined with still to express an ongoing resultative state:

(24) He is still gone. (Resultative)

(25) He has left. (Perfect with resultative character; cannot be combined with still)

In the case of resultative performatives we often find passive structures. The use of performatives with a passive or resultative-like construction has been remarked by Austin himself for English in passive sentences like Notice is hereby given. Similar passive constructions can be found in various other languages, such as Finnish (Volodin 1988: 473), Dutch (Janssen 1994: 135), Luganda (Ferrari-Bridgers 2009: 66), Xhosa (Andrason and Dlali 2017), and spoken Arabic (Naïm 2016). For example:

\section{(26) Olukiiko luno lu-komekkerez-edd-wa wano. (Luganda)}

meeting this it-adjourn-PFV-PASs now

'This meeting is now adjourned.' (Ferrari-Bridgers 2009: 66)

In all these cases, the verb refers to the state that starts as soon as the sentence is finished. This use is possibly typical for verdictives (where the speaker judges or gives a verdict) or exercitives (where the speaker exercises power, right or influence) in the sense of Austin or "declarations" in the sense of Searle, and as such probably often associated with the more official register. The passive construction is suitable in such contexts because it allows the speaker to not formally express the actor (Andrason and Dlali 2017). In Arabic the impersonal passive is used in directive-like and semi-performative sentences if it is not the speaker or the addressee who will carry out the requested action (Mughazy 2011) (cf. "The mentioned individual is to be summoned for questioning", where the questioning will not be done by the judge). A similar use is mentioned for modern Persian by Perry (2007), for what he calls performatives of "irrevocable intent”. In this case we find a regular past tense, but the passive-like meaning is part of the verb šodi 'become', or 'be' in a passive sentence: 
(27) Hamintowr raha šodi.

hereby free become.2SG.PST

'You are hereby freed' (Perry 2007: 999)

In order to further understand the relation between performatives and resultatives it is interesting to look at data from Dutch. In Dutch, performatives can be expressed by bare past participles as in (28):

(28) Beloofd!

promise.PST.PTCP

'That is a promise.' (lit. 'Promised.')

This construction seems to be a shortened version of the corresponding passive perfect construction with a copular verb, for example:

(29) Dat is dan hierbij afgesproken.

that is then hereby agree.PST.PTCP

'By doing this, that is a deal (lit. this is agreed).'

This type of construction also occurs with an active perfect construction with hebben 'have':

(30) Dat hebben we dan bij dezen afgesproken. Akkoord?

that have we then hereby settled okay

'In that case it is hereby settled, okay?' (Janssen 1994: 135)

These sentences have the character of an assertive declaration in the sense of Searle, which partly refer back to a given decision and partly have a performative "confirming" character.

The bare participle is used is also used with a limited set of commissives and behabitives, e.g. Bedankt!; thank.PST.PTCP; 'Thanks!'; Gefeliciteerd!; congratulate. PST.PTCP; 'Congratulations!'; Gegroet! ; greet.PST.PTCP ‘Greetings!.’ Diachronic data show that these constructions are derived from imperative passive constructions. In the eighteenth and seventeenth century performative instances usually occur with an imperative and a participle: ${ }^{10}$

10 I looked in the corpus Brieven als buit, and in Google books. 


$$
\begin{aligned}
& \text { (...) weest vriendelyk gegroed en bedankt }{ }^{11} \\
& \text { be-IMP kindly greet.PST.PTCP and thank.PST.PTCP } \\
& \text { 'kind greeting and thanks (lit. be kindly greeted and thanked)' }
\end{aligned}
$$

In many instances the passive nature of such constructions is made clear by the use of a prepositional phrase which expresses the agent of the action, for example in the phrase often used at the end of letters blijft hier bij gegroet van .... (lit. be (remain) hereby greeted by ...). The data suggest that the performative construction with a bare participle evolved out of an imperative construction with a passive meaning or sometimes a passive construction with worden ('become') without imperative, which was used in more or less set ("ritualized") settings. This led to an idiomatic and shorter performative construction with a bare participle without imperative or passive meaning. We see the diachronic development of a construction which first expresses a directive to get into a (resultative) state or a passive construction (e.g. 'you are becoming (being) greeted by $x^{\prime}$ ) into the construction that we find today, which expresses a state (result) only. The bare participle performative is limited to a closed set of verbs, such that one cannot say I baptize you with a bare participle ( ${ }^{\star}$ gedoopt; baptized.PST.PTCP). As such, the Dutch data cannot be seen as a typical instance of the anterior path cline as discussed in the previous section, even though it does support the general hypothesis that resultatives and performatives are inherently connected. It also shows that performatives may show special idiomatic grammatical properties due to their ritualized character.

\subsubsection{Progressive}

In this section I will discuss progressive performatives. The term "progressive" can be used in a broad sense for specialized constructions or TA-markers that express an "ongoing activity" (Dahl 1985: 91), but as I will show, this description is too broad to describe language specific uses of such constructions. As is remarked by Comrie (1976) it is possible to see progressives as a subcategory of the more general imperfective category. This can be clearly illustrated with Russian, where the imperfective has various uses, ranging from habitual uses to progressive uses. Unlike English, however, Russian has no dedicated progressive construction. In this section I will only discuss dedicated progressive constructions.

11 Verzaameling van eenige geestelyke brieven. Jan Luyke, 1741. 
Bybee and Dahl (1989: 82) argue that the progressive is absent with performatives in their sample of languages. This is largely confirmed by my data. There are, however, a few languages where the progressive seems to be a standard construction for performatives, and there are even more languages where progressive performatives are used to convey special pragmatic effects (for example English). Mongolian is a language where the progressive (expressed with an imperfective converb) seems to be a standard form to express performatives (Binnick 2012: 82). The following sentences exemplify this use:
Bi amlaž/tangaraglaž
bai-na.
I promise/swear.CONV.IPFV be-PRS
'I promise/swear.'

The Mongolian imperfective converb describes a continuous action, that precedes, accompanies or modifies that of the main verb. (Binnick 2012: 26). It can be used in progressive-like sentences:

\section{(33) Yuu xii-j bai-na ve? \\ what do-IPFV be-PRS QP \\ 'What are [you] doing?' (Binnick 2012: 5)}

Janhunen (2012: 239-240) remarks that to refer to the present there are three relevant constructions in Mongolian, namely the aspectually neutral presentfuture tense, the aspectually marked habitual and the complex durative of the progressive construction as in (33). He argues that the temporal reference of the basic present-future depends on the Aktionsart of the verb such that in the case of stative events it refers to the present (e.g. 'know'), whereas in the case of dynamic events it refers to the future. This may explain why performative verbs, which usually express telic events, are better expressed by the progressive than by the basic present-future. Note, however, that the progressive can also be used with non-telic (stative) verbs like 'know' in stylistically marked contexts, and Binnick (2012: 82) remarks that the progressive is also used in the case of expressions such as 'I think'. The situation in Mongolian, where various forms can be used for performatives ((evidential) past tense markers (-lee, $-v$ ) and the progressive), is clearly complex and needs further analysis. ${ }^{12}$ Another language where the progressive probably is a standard way to express performatives is Chichewa (Bantu) as described by Kiso (2012). In Chichewa, performatives can

12 Brosig $(2014: 11,13)$ argues that the basic present-future with -na and the past non-imperfective with $-z E$ can be used in performatives in Khorchin Mongolian. 
occur either with the present progressive suffix - $k u$ - or with zero marking on the verb (a disappearing use, which seems to indicate a simple present):
Ndi-lonjez-a
ku-bwera mawa.
1SG.SBJ-promise-FV INF-come tomorrow
'I promise to come tomorrow.' (Kiso 2012: 95)

\section{(35) Ndi-ku-lonjez-a ndi-ku-pedz-a mawa. \\ 1SG.SBJ-PRS-promise-FV 1SG.SBJ-2SG.OBJ-find-FV tomorrow \\ 'I promise to come (lit. find you) tomorrow.' (Kiso 2012: 93)}

The performative with - $k u$ - focuses on the 'right now' present, perhaps reinforcing the performative utterance, and does not seem to be marked like the English progressive performative. In Chichewa this form is possibly evolving into a general present.

Giorgi and Pianesi (1997: 166) explain the restriction on the progressive performatives by arguing that the use of the progressive implies that there are two separate events, namely the speech event and the event referred to be the verb. Because of this, the use of the progressive is not strictly performative but refers to an event that has started before the moment of speech and will continue after that, in contrast to the simple present where the speech event is the same as the event referred to by the verb. This progressive construal is associated with specific pragmatics. Lin (1979: 41) argues for Mandarin Chinese that in the case of a performative with a plain form, the speaker is in the position to see the event as a complete whole and perform the action. In the case of the progressive aspect (wo zai wen ni 'I am asking you'), the use of the progressive marker zai arises from the speaker's feeling that the act of communication is blocked and incomplete, as such giving rise to the message "Do you hear me? I am asking you a question.” In the same vein, Bartschat (1977: 631), claims that the use of English progressive performatives has an emphasizing character, and De Wit et al. (2018) speak about the intention of the speaker for the performative act "to stand out". According to them, this explains why progressive performatives in English occur mainly with verbs with a directive character which have a more urgent character (warn, order, request), whereas they are virtually absent with expressives (thank, apologize) and commissives (promise, swear). In my view, the use of progressive performatives also has to do with the fact that the event is not solely restricted to the moment of speech. This is for example the case with I am firing you, where the event of firing is presented as something that may have been prepared before that, or even continue after the moment of speech. This also explains why the simple present is hardly acceptable ('I fire 
you.), and why one can also use a present tense with be, which presents the act as something which is already in place (You are fired! Donald J. Trump in "The Apprentice"). It also explains why commissives such as 'promise' can be used in the progressive if the speaker wants to emphasize the validity of the promise as not being linked solely to the moment of speech, for example:We won't leave, I'm promising that (cf. You can be sure of that). ${ }^{13}$ This can be compared to the commissive swear which has a more inherent performative and conventionalized (ritualized) character that is inherently linked to the moment of speech, which explains why the progressive is almost excluded ('I am swearing I won't do that.).

Note that in languages where the progressive has a more specialized durative meaning performative uses may be fully excluded, in contrast to English. To give an example, in Dutch the periphrastic progressive construction with 'aan het + INF' cannot be used in performative contexts:

$$
\begin{aligned}
& \text { ?Ik ben je aan het waarschuwen. } \\
& \text { I am you on the warn.INF } \\
& \text { [intended meaning: 'I am warning you.'] }
\end{aligned}
$$

The reason for this is that the Dutch progressive construction presents an ongoing event in which the subject is actively engaged. This meaning is not in accordance with the function of the performative speech act. The English progressive, however, is more grammaticalized than its Dutch counterpart (see for example Ebert 2000: 605) and has a broader array of uses. Generally, in languages where the general present tense form does not express habitual events (e.g. Gawri), the difference between a progressive and a general present tense is not easy to make. This is probably also true for the imperfective presentative in Wolof and the progressive or imperfective present in Khoekhoe, which both occur in performative contexts. In both cases it is difficult to determine whether these forms should be analysed as progressive constructions or as more general imperfective constructions. Another interesting example is the conjunctive in Aleut which is used in sentences that have the character of a performative (e.g. 'Yes I thank you.'; Bergsland 1997: 86). The conjunctive can be said to have a progressive function since it is used to indicate an ongoing activity or act in progress. At the same time, however, the conjunctive is used for directive expressions and other non-progressive uses. Furthermore, other progressive functions can also be expressed by other markers such as the present. This clearly shows that the label 'progressive' has to be defined, in

13 Example taken from the NYT (September 25, 2001) 
the end, in a language specific manner, even if it is possible to compare different instances across languages.

\subsubsection{Future tense}

In my sample, the use of the future tense in performatives is relatively infrequent. However, many languages seem to allow for the use of future tense forms in performatives to create specific pragmatic (intersubjective) effects. Note that in the section I do not discuss the use of imperfective forms that can also have a future reference (as in for example Badiaranke or Tzotzil), but only dedicated future forms.

Zeisler (2004: 477) writes that in (Lhasa) Tibetan performatives are expressed by the simple (common) present, but also by the common future tense. The example she provides contains the verb 'promise':

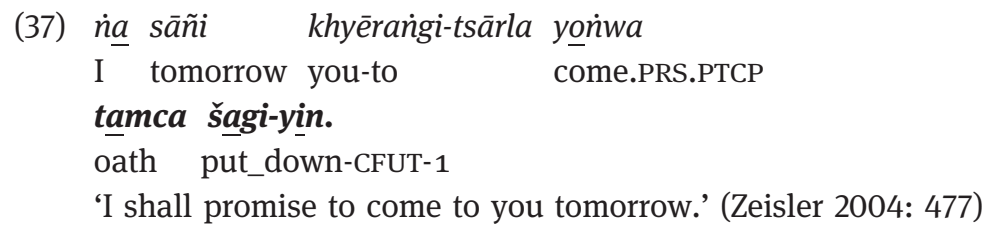

Zeisler (2004: 477) attributes this use to the non-continuous character of performatives, which is in accordance with the perfective or holistic character of the common future (Zeisler 2004: 522).

Within Slavic, Bulgarian has a special position because both the perfective future tense and the imperfective future tense are used in performatives. Like in Slovene, which I discussed in Section 4.1.3, the perfective present by itself has no future tense meaning, and the perfective present is not used in performatives. Slavkova (2017) argues that in Bulgarian three forms can be used in performatives, namely (i) the imperfective present, (ii) the analytical perfective future, and the (iii) analytical imperfective future. The analytical future tense is formed with the particle šte and the present tense (either imperfective or perfective). For example: (imperfective) present tense Vi molja ('I ask you.'), imperfective future tense šte Vi pomolja ('I will ask you.'), and perfective future tense šte Vi pomolja ('I will ask you.'). In performative constructions, some verbs only allow for the imperfective present, for example 'name', 'appoint', 'pardon', 'forbid', 'invite', 'propose'. Other verbs allow for the imperfective present and the analytical perfective future ('wish', 'stress', 'remind'). Finally, some verbs allow for all three forms (the imperfective present, the analytical perfective future, and the 
analytical imperfective future) ('ask', 'advice'). Slavkova (2017) offers a pragmatic account of the differences in terms of politeness, and argues that while the forms in the present (which are only imperfective) are more neutral, the future tense forms are more connected to politeness. This presence of a special pragmatic force associated with future tense performatives seems to be a more general crosslinguistic property. According to Brown and Levinson (1987: 166) in Tamil, the use of a future marker with an explicit performative is a way to hedge the performative that is normally in the present tense. They provide the following examples with the verb 'say':
a. Avaar varra maaTTaan enkireen. he come NEG I.say
'I tell you he won't come.'
b. Avaar varra maaTTaan enpeen.
he come NEG I.will.say
'I will say he won't come.'

This use of the future tense is probably reminiscent of the use in English, where will is used to emphasize (hedge) the performative. By using will with promise as in (39) emphasizes that he really promises something (as implicitly opposed to something else):

(39) I will promise you this, that if we have not gotten our troops out by the time I am President, it is the first thing I will do. ${ }^{14}$

A comparable use of the future tense can also be found in Dutch with specific verba dicendi such as zeggen 'say', where the use of zullen has an intersubjective character, and underlines that something is really the case ('maybe you do not think this, but...'):

(40) Ik zal je zeggen dat zo'n Narwal

I will you say.INF that such_a Narwhal van heel dichtbij best indrukwekkend is!

from very close rather impressive is

'I will tell you that such a Narwhal is rather impressive seen from nearby.'

Such uses are quasi-performative (see also Gonçalves 2015, for similar future tense uses in Latin, e.g. Now I will tell you.). It can be expected that several

14 https://www.azquotes.com/quote/679733 
languages have such specialized forms, which will not be listed in standard (descriptive) grammars.

Future tense forms are also used in more specialized performatives. There seems to be a relation between future tense performatives and spells. This is remarked by Faraone (1995) for Classical and Hellenistic Greek. Even though spells generally prefer the first-person present tense ('I bind so-and-so'), in some cases the future tense is used. According to Faraone, these cases are inherently performative and not all these cases can be described as the poetic expression of present intent or as a dramatic touch that vivifies the moment just prior to the performance of the ode. The Greek examples are reminiscent of West Tibetan, where the future tense can be used (besides the common present/future) in performatives if the speaker feels a certain gap between the event and the speech act (Zeisler 2004: 717-718), for example in the case of spells such as 'Now, I transform all the stones into bread!'.

Finally, the use of the future tense may also be related to the meaning of the verb. This is for example the case in the following example from Basque:

\section{(41) Itsasontzi honen izena Txapela izango da. sea-vessel this.GEN name Txapela be.FUT AUX 'The name of this boat will be Txapela.'15}

In this case this sentence not only has a performative character, but also an actual future tense character, because from the moment the sentence is uttered the name of the ship will be 'Txapela'. As such this sentence cannot be seen as a performative in the strictest sense.

\subsubsection{Mood and evidentiality}

In my sample there are few or perhaps no languages where performatives are standardly expressed by marking with a special (non-indicative) mood. The wellknown performative evidential mood in Kashaya is not used for actual performatives (Gene Buckley pc) and I have found no languages with a special performative mood such as an 'effektivus', a term for coined by Koschmieder for a special performative marking in a hypothetical language (1945: 28). In many European languages, however, the use of the subjunctives or modal verbs can have the character of a "polite performative" with verba dicendi, where by expressing the wish to say or ask something, something is actually said or asked:

15 https://eu.wikipedia.org/wiki/Esaldi_gauzatzaile. 
(42) a. I would like to remark, that.. (English)

b. Ja xotela by otmetit', čto... (Russian)

I want.PST IRR remark.INF that

'I would like to remark that...'

See also Fraser (1975) for so-called hedged performatives in English in sentences like I must request, etc. In my sample, an irrealis form was also used in Berber (instead of the regular imperfective or perfective) in the following sentence, probably to indicate in a polite manner that the speaker wants to perform the act of moving to another topic:

rexxu ad rahey far ijj $n$ lmuduc nneḍi
now NON-REAL I.go.AOR to one of topic other
[in a text]: 'I now move to another topic.'

In two languages in my sample performatives are expressed by evidential marking on the verb. In Imbabura Quechua (Kwon 2013) performatives seem to be expressed by a plain verb form and the evidential-epistemic modal marker (validator) -mi:

(44) nyuka ni-ni-mi kan-kuna kosa warmi ka-ngi-chi.

1SG say-1SG-mi you-PL husband wife be-2PL-CAUS

'I pronounce you husband and wife.' (Kwon 2013: 74; the example was constructed by him and judged to be natural according to his consultant)

In Georgian, the perfect, which has an evidential meaning, can be used with specific types of performatives (see (15)) and in Mongolian the evidential past tense marker -lee is found in performatives (see Section 4.1.4). Boeder (2000: 307-308) explains the perfect in Georgian by arguing that by uttering a proposition which anticipates its becoming true, the speaker makes it becomes true, but also remarks that this use could already be found in Old Georgian, when the perfect did not yet have an evidential meaning. As such the performative use of probably not based on the evidential meaning.

\subsection{Conclusion of crosslinguistic overview}

The overview presented here shows that performatives can be expressed by several different TA(M)-markers. In Table 2 an overview is given of the types found in my sample of 106 languages. Even though the data are collected with 
Table 2: Overview $\mathrm{TA}(M)$ in performatives.

\section{PERFORMATIVE CONSTRUCTION LANGUAGES WHERE THIS TA(M)-TYPE IS FOUND IN MY SAMPLE}

A. No TA-marking (languages without tense and gramm. aspect) [8]

B. Present/Imperfective Present ${ }^{*}[63]$

Imperfective (incompletive) ${ }^{\star \star}[12]$

C. Perfective present in Slavic [5]

D. Perfective (non-present) Perfect [6]

'Factative' ${ }^{\star \star \star \star}$ [4]

Perfective [24]

Perfective Past [5]
Ambel, Burmese, Chinese (Mandarin), Kilivila, Moskona, Tukang Besi, Rengoa, Vietnamese

Albanian, Aleut, Armenian, Basque, Bulgarian, Catalan, Cherokee, Chibemba, Czech, Dolakha Newar, Estonian, Finnish, Dutch, French, Gawri, Georgian, Greek (modern), Ancient Greek, Hittite, Hindi, Hungarian, Icelandic, Italian, Japanese, Khoekhoe, Kom, Korean, Kurdish, Lezgian, Luganda, Malagasy, Malayalam, Mbili, Moksha, Nyakyusa, Old Church Slavonic, Persian, Polish, Punjabi, rGyalrong (nonpast), Russian, Sanskrit, Slovene, Spanish, Swahili, Tajik Persian, Tamil, Totonac, Tibetan, Turkish, Early Vedic, Wampis, Welsh, Colonial Valley Zapotec, Yup'ik, Zulu Simple present tense [i.e. not marked for aspect, minimally inflected, in opposition to imperfective/ progressive present]: Breton, Chichewa, English, Purépecha?, Imbabura Quechua, South Conchucos Quechua, Shupamem

Amharic, Arabic, Ge'ez, Tigrinya, Badiaranke, Hausa, Poqomchi', Xhosa, Yukaghir, Tarifiyt, Totonac, Tzotzil

Peripheral: Czech, Polish, Russian

Non-peripheral: Slovene, Old Church Slavonic

Peripheral: Dutch, Georgian, Old Novgorodian Russian Possibly non-peripheral: Mandinka, Colonial Valley Zapotec (combined with simple present/habitual), Classical Egyptian (possibly better analysed as a perfective)

Past reference with dynamic verbs: Ewe (aorist), Wolof (perfect), Lingala (present perfect), Tarifiyt (perfective) PFV closely associated with past: Amharic, Arabic, Ge'ez, Ancient Greek, Hausa, Hebrew (Biblical), Mandinka, Northern Iroquoian languages (Mohawk, Oneida, Onondaga), Xhosa (peripheral), Siamou, Ugaritic, Zarma PFV also denoting immediate past: Kirundi, Luganda, Lucazi, Mian, Mongolian, Oku, ${ }^{\star \star \star \star}$ Totonac PFV other: Karuk?, Kom, Early Vedic (aorist injunctive) Akkadian (possibly better seen as perfective); Peripheral use: Tajik Persian, Persian, Georgian (perfective aorist), Old Novgorodian Russian, Early Vedic 
Table 2: (continued)

\section{PERFORMATIVE CONSTRUCTION LANGUAGES WHERE THIS TA(M)-TYPE IS FOUND IN MY SAMPLE}

E. Resultative/passive [8]

F. Progressive [8]

G. Future [11]

H. Mood/Evidentiality [8]

I. Other [4]
Amharic, Arabic, Xhosa, Dutch, English, German, Finnish, Luganda

Albanian (po), Chichewa, Mongolian, English, Karuk?, Luganda, Wolof (presentative plus imperfective marker), Colonial Valley Zapotec, Modern Valley Zapotec $^{* * * * *}$

In specialized contexts/pragmatically marked: Basque, Old Church Slavonic, Ancient Greek, English, Dutch, Karuk?, Sanskrit, Tamil, Totonac Possibly less marked: Tibetan, Bulgarian

In specialized contexts/pragmatically marked:

Albanian, Tarifiyt, Dutch, English, Georgian, Mongolian, Modern Greek, Early Vedic

Possibly not marked: Imbabura Quechua (evidential combined with present tense marking)

Akan (habitual [factative]), Aleut (conjunctive), Purépecha (habitual [imperfective]), Manambu (versatile tense for ongoing, recent and future events)

\footnotetext{
*Additional remarks. - In Aleut and Yup'ik the present tense can also indicate an immediate past. Miyaoka (2012: 1210, 1211) analyses the present tense in Yup'ik as an indicative non-marked for tense and aspect. In Chibemba the present can also refer to a future event. - In Finnish and Estonian, the perfective aspect is sometimes said to be expressed by the case marking of the direct object, rather than by the verb itself (see also Dahl 1985). I have classified these instances as "present" (cf. Dahl 1985: 69) - Some linguists argue that Japanese has an imperfective-perfective system (e.g. Martin 2004). - The imperfective present in Khoekhoe is sometimes analysed as a progressive present. - In Turkish, both the iyor- present and the so-called "aorist", which also expresses present events (Johanson 1971: 122-125). - The boundary between the category "simple present" and "(general) present" is not discrete since many languages have a present opposed to a periphrastic present progressive. The examples given here are labelled as such in the literature. ${ }^{\star *}$ In all of these languages the imperfective is strongly associated with a present tense reading, especially in Arabic. This explains why there may be disagreement about whether a form should be classified as an imperfective or a present. See also Vinogradov (2016) for a discussion about tense and aspect in the Mayan languages.

${ }^{\star \star *}$ The interpretation as a past event in the case of dynamic verbs can also be found (to varying degrees) in other languages such as Hausa and Mandinka, which shows that the classification is to some extent artificial.

${ }^{* * * *}$ The status of the unmarked present as a perfective is not fully clear from Nforbi (1993).

${ }^{* * * * *}$ Possibly, the progressive in some varieties of modern Zapotec is better analysed as an imperfective, even if in some other varieties (e.g. Mitla) the progressive is opposed to the habitual and the stative.
} 
great care many languages probably allow for various types of performatives, which are probably not always listed in grammars, or not found by me (e.g. subjunctive, future tense or progressive performatives). Nevertheless, the data give a good general overview of the types of TA(M) in the case of performatives. Quite a few languages do in fact employ various TA(M)-markings for various different subtypes of performatives, which means that many languages appear in different categories in the table. The capital letters in the table follow the categorization introduced in Section 4.1.

The data show that the most frequent TAM-type for performatives is the (non-aspectually marked) present tense. As the overview shows the (perfective) past tense almost never occurs in performatives. The use of perfective performatives is restricted to Slavic, where a perfective present is used, to languages with a (non-tensed) perfective imperfective structure, a factative, or to languages where the perfective denotes an immediate past with present relevance. Within the group of languages that have such TAM-constructions, the use of the perfective performative is not infrequent, as is shown in Table 3 (see appendix $\mathrm{C}$ in the supplementary material for an overview of the TAM-systems of all languages in my sample). Note that strictly speaking Xhosa and Zulu are not part of this category since the recent past tense marker -ile does not express an immediate past ("just done") and it is not clear to me whether it must be categorized as a perfective past, but I have included these languages since -ile can have present time reference with inchoative verbs.

Table 3: Performatives in languages with a perfective/imperfective structure, factative, perfective present, or perfective denoting an immediate past.

\begin{tabular}{|c|c|c|c|}
\hline Perfective [16/17] & $\begin{array}{l}\text { Imperfective/Perfective } \\
\text { [15/17] }\end{array}$ & $\begin{array}{l}\text { Imperfective } \\
\text { (Perfective) } \\
{[2 / 3]}\end{array}$ & Imperfective [13] \\
\hline $\begin{array}{l}\text { Ewe, Early Classical } \\
\text { Egyptian, Biblical } \\
\text { Hebrew, [Karuk?], } \\
\text { Kirundi, Lingala, } \\
\text { Lucazi, Mandinka, } \\
\text { Mian, Mohawk, Oku, } \\
\text { Oneida, Onondaga, } \\
\text { Siamou, Ugaritic, } \\
\text { Wolof, Zarma }\end{array}$ & $\begin{array}{l}\text { Amharic, Modern } \\
\text { Standard Arabic, Spoken } \\
\text { Arabic, Classical Arabic, } \\
\text { Bulgarian, Ge'ez, Ancient } \\
\text { Greek, Hausa, Kom, } \\
\text { Luganda, [Mongolian], } \\
\text { Old Church Slavonic, } \\
\text { Slovene, Tarifiyt, } \\
\text { Totonac, Early Vedic, } \\
\text { [Zapotec (Colonial } \\
\text { Valley)?] }\end{array}$ & $\begin{array}{l}\text { Czech, } \\
\text { [Xhosa], } \\
\text { Russian }\end{array}$ & $\begin{array}{l}\text { Badiaranke, Japanese } \\
\text { [according to some a } \\
\text { present tense], } \\
\text { Khoekhoe, Nyakyusa, } \\
\text { Purépecha, Quechua } \\
\text { (South Conchucos), } \\
\text { Shupamem, Tigrinya, } \\
\text { Tzotzil, Yukaghir, } \\
\text { Wampis, Zapotec } \\
\text { (Modern Valley), Zulu }\end{array}$ \\
\hline
\end{tabular}


Not all languages with a present marked for the perfective use this form for performatives. An example is Wampis, which uses the imperfective (with zero marking, which indicates a present) for performatives, and not the present marked for the perfective, which also expresses a "just done" action. The difference is that the perfective present in Kirundi, has a looser time reference than Wampis, and covers a recent past, the present up to an immediate future. This meaning is in accordance with the performative. In the same vein, in Yukaghir the perfective is very strongly linked to a past event, which explains why it is not used in performatives. In the Bantu languages Nyakyusa, the recent past (Xhosa and Zulu) or perfective present (Nyakyusa) -ile is not used in performatives, with the exception of a small set of verbs in Xhosa. In this case, it seems, the marker -ile is too closely associated with a past event (not necessarily with a "just done" semantics) and the present tense is a more optimal candidate for performatives.

If we turn back to the hypotheses given in the beginning of the article, we can now provide the following answers:

1. In languages with a perfective/imperfective distinction, the imperfective is chosen in the case of performatives (Verschueren 1995) and perfective performatives do not exist (Hewson 2012). If a language has a general imperfective form, this form will be chosen for performatives (De Wit et al. 2018). Counterexamples to these hypotheses can be found in Slavic languages (especially Slovene), various Afro-Asiatic languages (for example Arabic and Tarifiyt), Niger-Congo languages (e.g. Siamou, Luganda) and languages in America (Northern Iroquoian, Totonac) and Mian in Asia. At least some of these perfectives (e.g. Slovene) cannot be seen as instances of the "Performative" in the sense of Hewson. In my sample, the number of languages that can only use a perfect(ive) in performatives is smaller than the number of languages that can only use a present or imperfective, but this is the case because most languages have a present tense which is used for performatives, and lack a non-tensed perfective, or perfective present.

2. Perfective (perfect) performatives are (or are derived from) resultative constructions (Andrason 2012, Andrason 2016). Even though this hypothesis may explain some performative uses in some language, it cannot explain all perfective (perfect) performatives.

3. Past (including perfect) performatives refer back to an earlier (and separate) act (Dekker 2018). No evidence has been found for this hypothesis, with the exception of the instances from Old Russian mentioned by Dekker (2018) himself.

4. The progressive is not used in performatives (cf. Bybee and Dahl 1989). This hypothesis seems to be sustained by the large majority of languages, but 
some counterexamples can be found in Mongolian and Chichewa and even to some extent English.

5. The TAM of the performative equals the TAM of the reportive present, historical present or other constructions which express coincidence (Dahl 1985, cf. Koschmieder 1930; De Wit et al. 2018). There is indeed a correlation between the TA(M) of performatives and the TA(M) of reportives, as suggested by Dahl (1985), but this correlation is not absolute.

Based on the data from my sample, we can modify or extend the existing hypotheses as follows, building in a hierarchy and some conditions for the use of the perfective:

a) In languages without obligatory TA-marking, the performative is expressed by a verb not marked with specialized aspectual markers, probably because there is no inherent need to put extra emphasis on things like completion or progress as the inherent temporal structure of the event is already evident from the speech act itself.

b) If a language has an "all purpose" present tense such as the English simple present, this tense is used for performatives. This rule does not hold for languages with an imperfect(ive) perfect(ive) structure, where the imperfect(ive) is strongly associated with the present, but where the perfective is not exclusively restricted to the past.

At first sight, possible exceptions to this rule are Akkadian (preterite performative and not the present), Mongolian (progressive performative and not the present-future), and Oneida (factive-punctual performative and not the (present) serial). In Oneida, however, the serial is possibly too much associated with a progressive meaning. Mongolian has so many present tense constructions that it is incorrect to speak about an all-purpose present tense. The Akkadian preterite originally functioned as a (non-tensed) perfective and never had a strict past tense character, since it was also used to refer to present gnomic events (Von Soden 1995), which might explain its performative use.

c) In languages which have the following tenses - present, (perfective or imperfective) past, and perfect - the performative will be in the present only, with the exception of languages where the perfective past can also be used more broadly to refer to present events (Ancient Greek); see point (f). Perfect constructions, which are typical for the European languages, do usually not seem to occur with performatives, with the exception of some resultative constructions. A possible explanation is that the retrospective point of view is not in accordance with the performative speech act. The only exception to this rule is Old Novgorodian Russian, for which Dekker (2018) argued that the 
perfect in performatives (aorist and perfect) actually functioned to refer to a past event and did not have a strict performative function.

d) In languages with a (tenseless) perfective-imperfective (or perfect-imperfect) system, the performative is expressed by the imperfective (Badiaranke, Tzotzil, Yukaghir, Tigrinya), by the perfect(ive) (Biblical Hebrew/Ugaritic, Zarma, Mian), or both by the imperfect(ive) and perfect(ive), each with a different meaning and usage (Tarifiyt, Hausa, Arabic, Totonac). The exclusion of the perfective in Tzotzil, Yukaghir, Tigrinya is probably due to the stricter past time reference of the perfective, but this is not the case in Badiaranke, such that the absence of the perfective (factative) in performatives in this language is somewhat unexpected.

e) In Slavic languages with a perfective present tense, and imperfective present tense we find both aspects in performatives, even though there are clear differences between languages with respect to the use of the perfective present. In languages where the perfective is more prevalent (Slovene), there are some verbs which always require the imperfective, but there seem to be no or few verbs that do not allow for an imperfective.

f) In languages where the perfect(ive) is used for performatives, the perfect(ive) has no strict past time reference and/or is also used in other instances where the event referred to be the verb either fully coincides with the moment of speech or is closely associated with the moment of speech ("immediate past"). In many instances this verb form is used for the reportive "present" (e.g. Kirundi, Kom, Lingala, Mongolian), or can otherwise have a close association with the present (e.g. Modern Standard Arabic, spoken Arabic, where the perfective can be used to refer to some present events).

g) Some TA(M) markers seem to be used primarily in the case of pragmatically marked contexts, such as expressions of modality, the future tense, and the dedicated progressive (durative) markers. The occurrence of the progressive as the default way to express performatives in a few languages can be explained with respect to the system in which they occur. More in particular, in some languages the progressive is probably better analysed as an imperfective, which is used in performatives because the other forms that can have present reference are not suitable.

\section{General conclusion}

As I have shown, there is not one relation between performatives and a particular tense and aspect and there are no languages which have a special 
(dedicated) performative tense or aspect marker. Instead, performatives are compatible with various tense and aspect markers, even though the use of a present tense seems to be the most common. How, then, can we explain why performatives occur with various TA(M) markers, even though some markers (present) seem to be more widely attested than others (for example the progressive or perfective)? For this explanation, we can turn to two general principles of semantics, namely (i) the principle that in many cases there are different ways of viewing the same situation ("construal”) and (ii) the principle that what counts as the most optimal meaning depends on the division of labor within the linguistic structure. A third general principle, that the meaning of the form must be explained with reference to the actual setting in which the meaning is used, which may differ from culture to culture, turned out to be less relevant in the explanation of the data. I will briefly discuss these principles below.

First, because of their functional nature performatives are compatible with various meanings across languages (cf. Koschmieder 1945: 28-29). It is possible that a language selects a meaning for the performative which presents the performative as an instance of coincidence or overlap between the event expressed by the verb and the speech act, in which case a present tense or imperfective (with a strong association with present reference) is used in languages with tense and/or aspect. In some Slavic languages (Slovene and Old Church Slavonic), in such cases both a perfective present and an imperfective present can be used, depending on whether the event is seen as a totality (fully coinciding with the moment of speech) or not. It is, however, also possible that the event is denoted as something that has just been realized the moment the sentence is finished, in order to stress the result of the performative. In that case a perfective, factative or present perfect(ive) is used, which can also refer to an immediate past event. Resultative constructions present an intermediate case since they denote the performative by a current resultative state. In some languages (for example Bulgarian or Tibetan) it is also possible that the event is construed as something that will occur after the moment of speech even if the context makes clear that the event is in fact already realized by uttering the sentence. In most languages, for example English (e.g. I will promise you this) such cases have a special intersubjective character, and may be associated with the future realization of the act associated with the promise, agreement, thought, etc. The data show that performatives are relatively infrequently expressed by dedicated progressive or durative markers. This relative infrequency of dedicated progressive markers can be explained with reference to the performative speech act. Specialized dedicated progressive, durative or continuous markers function to focus on the internal structure of the event, which is presented as having duration, for example such that it co-occurs with 
some other linguistically expressed event, or as something which has a continuative character. This is not very compatible with the performative speech act, which is a relatively short and bounded situation, with a clear beginning and an end, where the focus is on the result of the action. The use of the progressive therefore often has an intersubjective function in performatives. As such, the overview presented here clearly shows that many languages employ different types of TA(M)-marking for different types of performatives. Depending on the meaning of the lexical verb, the style and register, and the specific meaning the speaker wants to convey, languages often allow for more than one TA(M)marking and make optimal use of the linguistic system. I found no instances of fully specialized habitual markers that are used for performatives, which makes sense from a functional perspective, since performatives do not express a habit or repetition (habitual). However, in many languages forms that can express habitual events can be used for performatives, probably because languages sometimes make a distinction between a progressive, which presents the event as ongoing, and another present tense verb form which refers to nonprogressive present events (e.g. English simple present, habitual in Akan, habitual in Purépecha).

Second, the meaning of tense and aspect can only be determined with reference to the structure in which it operates and the division of labour between various TA(M)-markers. What counts as the most optimal TA(M) marking for performatives therefore depends on the language in question. My overview has shown some general principles (or perhaps tendencies). In a language with a (aspectually non-marked) general present tense form, this form will be chosen to express performatives. This is probably the case because in such languages the other tense forms cannot express full or near coincidence with the moment of speech. This principle accounts for the prevalence of present tense performatives in my sample since many languages have such a general present. Another principle is that in languages where we find a non-tensed perfective, factative, or perfective present, the perfective is only used in performatives, if that verb form has a looser time reference, and does not only refer to past events, but can also be used more generally to refer to present events. In such cases the use of the perfective stresses the completion of the action by performing the performative speech act. This principle accounts for the fact that even though both in Kirundi (Zulu) and Wampis (Jivaroan) the perfective present expresses an immediate past, only in Kirundi the perfective present is used for performatives. This is because in Kirundi, and not in Wampis, the perfective present can also be used more generally to refer to present events, whereas the imperfective present refers to a habitual or progressive event. In the end, whether or not the perfective is actually possible in performatives in a language depends on the question 
whether it is a more optimal candidate to express performatives than other verb forms.

Finally, I have investigated the hypothesis that the (perfective) past and perfect use of performatives in ancient languages of the Mediterranean and Middle East can be explained with reference to cultural practices. In such cases, one might hypothesize, the use of the past tense or perfect performative is related to the distance between the speech act itself and the act of writing (cf. Dekker 2018 for Old Novgorodian Russian). The research provided here is inconclusive as to whether this factor was relevant for other languages than Old (Novgorodian) Russian, but the data seem to suggest that this factor is not applicable crosslinguistically. The widespread use of perfective performatives in the ancient languages of the Mediterranean and Middle East seems to be the result of the aspectual properties of these languages.

It is possible that a more fine-grained analysis of individual languages will also provide a deeper explanation of the crosslinguistic data. At the same time, it would be preferable to get an even better insight into the question of whether there are general patterns or correlations in the use of TAM, by combining data from many languages, and by using systematic data collection such as the use of parallel texts. In this paper, I have pointed at such general patterns in a small case and only focused on performatives, but further study could look at various uses to see whether there is a logic to the way aspectual and tense functions are distributed over various TAM-categories in a language (cf. De Wit et al. 2018), considering the process of concept-formation and the formation of meanings in the linguistic structure (see Bartsch 1998). Such research could also provide more insight into to what extent one can compare notions such as "perfective", "imperfective" or "perfect” from a typological perspective. This study has also shown that besides crosslinguistic similarities between meanings of aspectual markers (Comrie 1976; Dahl 1985), there are also many differences. As such, notions such as "perfective" or "perfect" are too imprecise in some cases, and it remains to be seen to what extent one can postulate them as given categories. Further research should focus on this topic.

Abbreviations: 1/2/3 1st/2nd/3rd person; a agent; ab absolutive case; ag agentive nominalizor; aor aorist; appl applicative; aux auxiliary; caus causative marker; conv converb; cop copula; dat dative; dem demonstrative; decl declarative sentence-type suffix; deffut-I definite future I (Tibetan); det determiner; dir direct evidential; emph emphatic; disj disjoint; erg ergative; ep epenthetic vowel; fact factual mood; fin finite particle; foc focus; fut future; fv final vowel; gen genitive; inf infinitive; io indirect object; ipfv imperfective; irr irrealis; $\mathrm{m}$ masculine; msd masdar; neg negative; nmlz nominalization; nom 
nominative; obj object; oc object concord; opr object pronoun; ov objective version; pass passive; pfv perfective; pl plural; pot potential; prs present; prd predicator; prf/perf perfect; prv preverb; pst past; ptcp participle; prog progressive; punc punctual aspect; purp purposive; quot quotative; qp question particle; real realis mood; refl reflexive; sbj subject; sbst substantivizer; sc subject concord; sg singular; sg singular; term terminative case, vp vocalic prefix.

Acknowledgements: The following people, either native speakers and/or linguistic experts, were extremely helpful in my research: Ahmad Al-Jallad (MS Arabic), Felix Ameka (Ewe), Alex Andrason (Hebrew), Joan Baart (Gawri), David Beck (Totonac), Kate Bellamy (Purépecha), Elizabeth Bergman (Tunisian Arabic), George Aaron Broadwell (Zapotec), Gene Buckley (Kashaya), Claudine Chamoreau (Purépecha), Aleksandra Derganc (Slovene), Sebastian Fedden (Mian), Bram Jagersma (Sumerian), Karim Laaraj (MS Arabic), Ferdinand Mberamihigo (Kirundi), Stefan Höffler (Latin), Ketevan Gadilia (Georgian), Andrew Garrett (Karuk), Asghar Seyed Gohrab (Persian), Holger Gzella (Hebrew, Akkadian), Wilfrid Haacke (Khoekhoe), Marcia Haag (Cherokee), Alwin Kloekhorst (Hittite), Martin Kohlberger (Shiwiar), Stephen Huebscher (Hebrew), Stephen Houston (Classic Maya), Sylvanus Job (Khoekhoe), Maarten Kossmann (Berber), Sergey Loesov (Akkadian), Sasha Lubotsky (Sanskrit), Iztok Mikulan (Slovene), Khalid Mourigh (Berber), Zaryan Nuri (Kurdish), Kweku Osam (Akan), Alvin Parmar (Georgian), Stefan Savić (Xhosa), Keren Rice (Slave), George Saad (Shuar), Sopho Siashvili (Georgian), Franklin R. Thom (Karuk), Igor Vinogradov (Poqomchi', Tzotzil), Marijke van der Wal (seventeenth and eighteenth century Dutch), Muhammad Zaman (Gawri). I also wish to thank Adriaan Barentsen, Jaap Kamphuis and Willem Vermeer for their critical comments on an earlier version of this paper, Östen Dahl for providing me with the data from his 1985 book and his valuable suggestions, Astrid De Wit for providing me with the data of her survey, Michael Job, Martijn Knapen, who helped me as a student-assistant at the first stages of my research, and Merel van Wijk, who helped me with the editing of my paper. Finally, I also would like to express my gratitude to the two anonymous reviewers of my paper, who had excellent comments, which helped me to improve my paper considerably. 


\section{Appendix A: Linguistic families, genera and geographical areas of languages in sample.}

\begin{tabular}{|c|c|c|c|}
\hline Area & Family & Genus & Language \\
\hline \multirow[t]{7}{*}{ Africa } & \multirow[t]{2}{*}{ Niger-Congo } & $\begin{array}{l}\text { Atlantic-Congo (and } \\
\text { other non-Bantu) }\end{array}$ & $\begin{array}{l}\text { Akan, Badiaranke, Ewe, } \\
\text { Kom, Basse Mandinka, } \\
\text { Siamou, Wolof }\end{array}$ \\
\hline & & Bantu, Bantoid & $\begin{array}{l}\text { Chibemba, Chichewa, } \\
\text { Kirundi, Lingala, Lucazi, } \\
\text { Luganda, Mbili, Nyakyusa, } \\
\text { Oku, Shupamem, Swahili, } \\
\text { Xhosa, Zulu. }\end{array}$ \\
\hline & \multirow[t]{3}{*}{ Afro-Asiatic } & Chadic & Hausa \\
\hline & & Berber & Tarifiyt \\
\hline & & Semitic & $\begin{array}{l}\text { Akkadian, Amharic, Arabic } \\
\text { (classical, modern } \\
\text { standard, colloquial } \\
\text { variants), Egyptian } \\
\text { (Ancient), Ge'ez, Hebrew } \\
\text { (classical), Tigrinya, } \\
\text { Ugaritic }\end{array}$ \\
\hline & Nilo-Saharan? & Songhay & Zarma \\
\hline & Khoe-Kwadi & Khoe & Khoekhoe \\
\hline \multirow[t]{10}{*}{ Eurasia } & Basque & Basque & Basque \\
\hline & \multirow[t]{8}{*}{ Indo-European } & Germanic & Dutch, English, Icelandic \\
\hline & & Slavic & $\begin{array}{l}\text { Bulgarian, Czech, Old } \\
\text { Church Slavonic Polish, } \\
\text { Russian, Slovene }\end{array}$ \\
\hline & & Albanian & Albanian \\
\hline & & Greek & $\begin{array}{l}\text { Ancient Greek, Modern } \\
\text { Greek }\end{array}$ \\
\hline & & Romance & French, Catalan \\
\hline & & Indo-Iranian & $\begin{array}{l}\text { Gawri, Hindi, Kurdish, } \\
\text { Punjabi, Persian, Tajik } \\
\text { Persian, Classical Sanskrit, } \\
\text { Early Vedic }\end{array}$ \\
\hline & & Armenian & Armenian \\
\hline & & Celtic & $\begin{array}{l}\text { Breton, Welsh } \\
\text { Hittite }\end{array}$ \\
\hline & Dravidian & Tamil-Kannada & Malayalam, Tamil \\
\hline
\end{tabular}


(continued)

\begin{tabular}{|c|c|c|c|}
\hline Area & Family & Genus & Language \\
\hline & Uralic & Ugric & Hungarian \\
\hline & & Mordvinic & Moksha \\
\hline & & Finnic & Finnish \\
\hline & & & Estonian \\
\hline & Japanese & Japanese & Japanese \\
\hline & Korean & Korean & Korean \\
\hline & Nakh-Dagestanian & Lezgian & Lezgian \\
\hline & Kartvelian & Karto-Zan & Georgian \\
\hline & Altaic & Turkish & Turkish \\
\hline \multirow[t]{9}{*}{$\begin{array}{c}\text { South East Asia } \\
\text { and Oceania }\end{array}$} & Sino-Tibetan & Sinitic & $\begin{array}{l}\text { Mandarin Chinese } \\
\text { (Pekinese) }\end{array}$ \\
\hline & & Tibeto-Burman & $\begin{array}{l}\text { Burmese, Dolakha Newar, } \\
\text { Tibetan, Burmese }\end{array}$ \\
\hline & & Qiangic & Zhuokeji rGyalrong \\
\hline & Austro-Asiatic & Bahnaric languages & Rengao \\
\hline & & Viet-Muong & Vietnamese \\
\hline & Austronesian & Malayo-Polynesian & $\begin{array}{l}\text { Ambel, Kilivila, Malagasy, } \\
\text { Tukang Besi }\end{array}$ \\
\hline & Trans-New Guinea & $\begin{array}{l}\text { Central and South New } \\
\text { Guinea }\end{array}$ & Mian \\
\hline & West Papuan & East Bird's Head & Moskona \\
\hline & Sepik & $\mathrm{Ndu}$ & Manambu \\
\hline \multirow[t]{2}{*}{ North America } & Eskimo-Aleut & Eskimo-Aleut & Aleut, Yup'ik \\
\hline & Iroquoian & Southern Iroquoian & $\begin{array}{l}\text { Cherokee, Mohawk, } \\
\text { Oneida, Onondaga } \\
\text { Karuk }\end{array}$ \\
\hline \multirow[t]{8}{*}{ South America } & Quechuan & Quechuan & $\begin{array}{l}\text { Imbabura Quechua, South } \\
\text { Conchucos Quechua }\end{array}$ \\
\hline & Mayan & Greater Quichean & Poqomchi' \\
\hline & & Cholan-Tzeltalan & Tzotzil \\
\hline & Purépecha & Purépecha & Purépecha \\
\hline & Oto-Manguenan & Zapotecan & $\begin{array}{l}\text { Colonial Valley Zapotec, } \\
\text { modern Zapotec }\end{array}$ \\
\hline & & Mixtecan & Magdalena Peñasco Mixtec \\
\hline & Totonac & Totonac & Totonac (Upper Necaxa) \\
\hline & Jivaroan (Chicham) & Jivaroan (Chicham) & Wampis \\
\hline
\end{tabular}




\section{References}

Abbott, Clifford. 1981. Here and there in Oneida. International Journal of American Linguistics 47(1). 50-57.

Abboud, Peter \& McCarus Ernest. 1983. Elementary Modern Standard Arabic: Part 2. Cambridge: Cambridge University Press.

Andrason, Alexander. 2012. Making it sound - performative qatal and its explanation. Journal of Hebrew Scriptures 12(8). 1-58.

Andrason, Alexander. 2016. A complex system of complex predicates: Tense, taxis, aspect and mood in Basse Mandinka from a grammaticalisation and cognitive perspective.

Stellenbosch, South Africa: Stellenbosch University dissertation.

Andrason, Alexander \& Mawande Dlali. 2017. Tense and aspect of performatives in isiXhosa. South African Journal of African Languages 37(2). 149-161.

Austin, John L. 1962. How to do things with words. Oxford: Clarendon Press.

Bahloul, Maher. 2008. Structure and function of the Arabic Verb. London/New: York: Routledge. http://www.politicalavenue.com/languageschool/Arabic\%20Language\%20Learning\% 20Pack/22.Structure\%20and\%20Function\%20of\%20the\%20Arabic\%20Verb.pdf (accessed 30 July 2018).

Baker, Mark \& Lisa Travis. 1997. Mood as verbal definiteness in a tenseless language. Natural Language Semantics 5(3). 213-269.

Bartsch, Renate. 1998. Dynamic conceptual semantics. A logico-philosophical investigation into concept formation and understanding. Stanford, California: CSLI Publications.

Bartschat, Brigitte. 1977. Aspektgebrauch und Performativität [The use of aspect in Slavic languages and the concept of performativity]. Zeitschrift für Slawistik 22. 629-637.

Bary, Corien. 2009. Aspect in Ancient Greek. A semantic analysis of the aorist and imperfective. Nijmegen, Netherlands: Radboud Universiteit dissertation.

Bary, Corien. 2012. The Ancient Greek tragic aorist revisited. Glotta 88. 31-53.

Beck, David. 2011. Upper Necaxa Totonac dictionary. Berlin: Mouton de Gruyter.

Bergman, Elizabeth M. 2005. Spoken Algerian Arabic. Springfield, VA: Dunwoody Press.

Bergsland, Knut. 1997. Aleut grammar. Fairbanks: Alaska Native Language Center.

Binnick, Robert I. 1991. Time and the verb: A guide to tense and aspect. New York: Oxford University Press.

Binnick, Robert I. 2012. The past tenses of the Mongolian verb: Meaning and use. Leiden: Brill.

Boeder, Winfried. 2000. Evidentiality in Georgian. In Lars Johanson \& Bo Utas (eds.), Evidentials: Turkic, Iranian and Neighbouring languages, 275-329. Berlin/New York: Mouton de Gruyter.

Brisard, Frank \& Michael Meeuwis. 2009. Present and perfect in Bantu: The case of Lingála. Journal of African Language and Linguistics 30(1). 21-43.

Brosig, Benjamin. 2014. The tense-aspect system of Khorchin Mongolian. In L. J. Whaley \& P. Suihkonen (eds.), On diversity and complexity of languages spoken in Europe and North and Central Asia (Studies in Language Companion Series v. 164), 3-66. Amsterdam: John Benjamins Publishing Company.

Brosig, Benjamin. 2018. Factual vs. evidential? The past tense forms of spoken Khalkha Mongolian. In Ad Foolen, Helen de Hoop \& Gijs Mulder (eds.), Evidence for Evidentiality, 45-75. Amsterdam/Philadelphia: John Benjamins Publishing company.

Brown, Penelope \& Stephen Levinson. 1987. Politeness: Some Universals in Language Usage, Studies in interactional sociolinguistics 4. New York: Cambridge University Press. 
Bybee, Joan L. \& Osten Dahl. 1989. The creation of tense and aspect systems in the languages of the world. Studies in Language 13(1). 51-103.

Bybee, Joan L., Revere Perkins \& William Pagliuca. 1994. The evolution of grammar. Tense, aspect, and modality in the languages of the world. Chicago: The University of Chicago Press.

Carpenter, Kayla. 2014. Aspectual future in Karuk. Manuscript Berkeley University. http:// linguistics.berkeley.edu/ mikkelsen/papers/carpenter_2014.pdf (accessed 30 July 2018).

Comrie, Bernard. 1976. Aspect: An introduction to the study of verbal aspect and related problems. Cambridge: Cambridge University Press.

Comrie, Bernard. 1985. Tense. Cambridge: Cambridge University Press.

Croft, William. 2012. Verbs: Aspect and Causal Structure. Oxford: Oxford University Press.

Cuvalay-Haak, Martine. 1997. The verb in literary and Colloquial Arabic. Berlin: Mouton de Gruyter.

Dahl, Eystein. 2008. Performative sentences and the morphosyntax-semantics interface in Archaic Vedic. Journal of South Asian Linguistics 1(1). 7-27. https://www.researchgate. net/publication/251717422_Performative_Sentences_and_the_Morphosyntax-Semantics_ Interface_in_Archaic_Vedic (accessed July 17, 2018).

Dahl, Eystein. 2010. Time, tense and aspect in Early Vedic grammar: Exploring inflectional semantics in the Rigveda. Leiden: Brill.

Dahl, Östen. 1985. Tense and aspect systems. Oxford: Blackwell.

Daniel, Werning. 2008. Aspect vs. relative tense, and the typological classification of the Ancient Egyptian sDm.n = f. Lingua Aegyptia 16. 261-292.

David, Anne \& Sarah Goodman. 2013. Verbs. In Claudia Brugman (ed.), Descriptive grammar of Pashto and its dialects, 185-304. Berlin, Boston: Mouton de Gruyter.

De Wit, Astrid. 2017. The present perfective paradox across languages. Oxford: Oxford University Press.

De Wit, Astrid, Frank Brisard \& Michael Meeuwis. 2018. The epistemic import of aspectual constructions: The case of performatives. Language and Cognition 10(2). 234-265.

De Wit, Astrid, Michael Meeuwis, Frank Brisard \& Laura Michaelis. 2017. Aspect in performative contexts across languages. Unpublished presentation of the Beyond Time workshop. University of Colorado at Boulder, 7-8 April 2017.

Dekker, Simeon. 2018. Old Russian Birchbark Letters. A pragmatic approach, Series: Studies in Slavic and General Linguistics 42. Leiden/Boston: Brill/Rodopi.

Derganc, Aleksandra 2012. Performativnye glagoly v slovenskom jazyke [Performative verbs in the Slovene language]. Vestnik Moskovskogo universiteta 9. Filologija 6. 228-236.

Dickey, Stephen M. 2000. Parameters of Slavic aspect: A cognitive approach. Stanford: CSLI Publications.

Dickey, Stephen M. 2015. The aspectual development of performatives in Slavic. Zeitschrift für Slavische Philologie 71(2). 249-304.

Donohue, Mark. 1999. A Grammar of Tukang Besi. Berlin/New York: Walter de Gruyter and Co.

Ebert, Karen. 2000. Progressive markers in Germanic languages. In Östen Dahl (ed.), Tense and aspect in the languages of Europe, 605-653. Berlin: Mouton de Gruyter.

Faraone, Christopher A. 1995. The "Performative Future" in three Hellenistic incantations and Theocritus' second idyll. Classical Philology 90(1). 1-15.

Fedden, Sebastian. 2011. Grammar of Mian. Berlin: Mouton de Gruyter.

Ferrari-Bridgers, Franca. 2009. Luganda verb morphology: A new analysis of the suffixed [-YE] and $[-A]$ and their distribution across the indicative, subjunctive and imperative moods. Studies in African Linguistics 38(1). 52-79. 
Finnegan, Ruth. 1969. How to do things with words: Performative utterances among the Limba of Sierra Leone. Man, New Series 4(4). 537-552.

Fleisch, Axel. 2000. Lucazi grammar. Köln: Rüdiger Köppe Verlag.

Fortuin, Egbert \& Jaap Kamphuis. 2015. The typology of Slavic aspect: A review of the East-West theory of Slavic aspect. Russian Linguistics 39(2). 163-208.

Fortuin, Egbert \& Jaap Kamphuis. 2018. Unanswered questions of Slavic aspect: A reply to 'Thoughts on the 'Typology of Slavic aspect'. Russian Linguistics 42. 105-121.

Foster, Michael K. 1986. Updating the terminology of tense, mood, and aspect in Northern Iroquoian. International Journal of American Linguistics 52(1). 65-72.

Fraser, Bruce. 1975. Hedged performatives. In Peter Cole \& Jerry L. Morgan (eds.), Syntax and Semantics, vol. 3, 187-210. New York: Academic Press.

Friedman, Victor A. 1979. Toward a typology of status: Georgian and other non-Slavic languages of the Soviet Union. In Paul R. Clyne, William F. Hanks \& Carol L. Hofbauer (eds.), The elements: A parasession on linguistic units and levels, including papers from the conference on non-Slavic languages of the USSR, 339-350. Chicago: Chicago Linguistic Society.

Garrett, Edward John. 2001. Evidentiality and assertion in Tibetan. Los Angeles: University of California dissertation.

Giorgi, Alessandra \& Fabio Pianesi. 1997. Tense and aspect: From semantics to morphosyntax. New York: Oxford University Press.

Gonçalves, Rodrigo Tadeu. 2015. Performatives Plautus: Sophistics, metatheater and translation. Cambridge: Cambridge Scholars Publishing.

Greenberg, Marc. 2006. A short reference grammar of standard Slovene. Chapell Hill: SEELRC Reference Grammar Network. http://www.theslovenian.com/articles/2008/greenberg.pdf (accessed 12 July 2018).

Gregerson, Kenneth. 1971. Predicate and argument in Rengao grammar. University of Washington dissertation.

Haan, Sies de. 1991. Meaning and use of the Dutch perfect. In Jadranka Gvozdanović \& Theo Janssen (eds.), The function of tense in texts, 143-156. Amsterdam: North-Holland.

Hagman, Roy Stephen. 1973. Nama Hottentot Grammar. Colombia University Dissertation.

Haspelmath, Martin. 1993. A grammar of Lezgian. Berlin: Mouton de Gruyter.

Haspelmath, Martin. 2010. Comparative concepts and descriptive categories in crosslinguistic studies. Language 86(3). 663-687.

Hassellbach-Andee, Rebecca. 2015. Explicit Performative Utterances in Semitic. In Lutz Edzard (ed.), Arabic and Semitic linguistics contextualized: A festschrift for Jan Retsö, 448-485. Wiesbaden: Harrassowitz.

Hewitt, George. 1995. Georgian: A structural reference grammar. Amsterdam/Philadelphia: John Benjamins Publishing Company.

Hewson, John. 2012. Tense. In R. I. Binnick (ed.), The Oxford handbook of tense and aspect, 507-535. Oxford: Oxford University Press.

Hinrichs, Uwe. 1985. Der Koinzidenzfall in den Balkansprachen (I). Zeitschrift für Balkanologie 21(1). 136-151.

Hinrichs, Uwe. 1986. Der Koinzidenzfall in den Balkansprachen (II). Zeitschrift für Balkanologie 22(2). 165-184.

Hintz, Daniel J. 2011. Crossing aspectual frontiers: Emergence, evolution, and interwoven semantic domains in South Conchucos Quechua discourse. Berkeley/Los Angeles/London: University of California Press. 
Höfler, Stephan. to appear. 'I hereby present the use of the Latin 1st person perfect indicative as a performative'. In Proceedings of the 19th International Colloquium on Latin Linguistics (ICLL), 24-28 April 2017, Munich, Germany.

Holton, David, Peter A. Mackridge \& Irene Philippaki-Warburton. 1997. Greek: A comprehensive grammar of the modern language. Oxon: Routledge.

Ivanov, Sergej Ju. 2014. Upotreblenie vida v russkix performativax [The use of verbal aspect in Russian performatives]. In V I. P. Kjul'moja (ed.), Acta Slavica Estonica V. Trudy po russkoj $i$ slavjanskoj filologii: Lingvistika XVI. Antropocentrizm v jazyke i reči, 58-70. Tartu: Tartu University Press. https://pure.spbu.ru/ws/portalfiles/portal/18876609/ivanov_tartu2014. pdf (accessed 30 July 2018).

Jagersma, Bram. 2010. A descriptive grammar of Sumerian. Leiden: Leiden University dissertation.

Jaggar, Philip J. 2005. Performative constructions in Hausa. Afrika und Übersee 88. 157-174.

Jaggar, Philip J. 2006. The Hausa perfective tense-aspect used in wh-/focus constructions and historical narratives: A unified account. In Larry Hyman \& Paul Newman (eds.), West African Linguistics: Descriptive, Comparative, and Historical Studies in Honor of Russell G. Schuh, 100-133. London: J.M. Dent and Co.

Janda, Laura. 2004. A metaphor in search of a source domain: The categories of Slavic aspect. Cognitive Linguistics 15(4). 471-527.

Janhunen, Juha A. 2012. Mongolian, (London Oriental and African Language Library 19). Amsterdam/Philadelphia: John Benjamins Publishing Company.

Janssen, Theo. 1994. Preterit and perfect in Dutch. In C Vet \& Carl Vetters (eds.), Tense and Aspect in Discourse, 115-146. Berlin: Mouton de Gruyter.

Johanson, Lars. 1971. Aspekt in Türkischen. Vorstudien Zu einer Beschreibung der türkeitürkischen Aspektsystem (Acta Universitatis Upsaliensis, Studia Turcica Upsaliensia). Uppsala: Uppsala University Dissertation (Almqvist \& Wiksell (distr.))

Kamphuis, Jaap. 2012. Performativiteit, tijd en aspect in het Slavisch: Een diachroon perspectief. In René Genis, Erik De Haard, Janneke Kalsbeek, Evelien Keizer \& Jenny Stelleman (eds.), Between West and East. Festschrift for Wim Honselaar, 351-368. Amsterdam: Pegasus.

Kiso, Andrea. 2012. Tense and aspect in Chichewa, Citumbuka and Cisena. A description and comparison of the tense-aspect systems in three southeastern Bantu languages. Stockholm: Stockholm University dissertation.

Klimonov, Vladimir D. \& Gerda Klimonov. 2008. The connections between modality, aspectuality, and temporality in Modern Russian. In Abraham Leiss \& Elizabeth Leiss (eds.), Modality-Aspect Interfaces, 147-174. Amsterdam: Benjamins.

Koschmieder, Erwin. 1929. Zeitbezug und Sprache. Ein Beitrag zur Aspekt- und Tempusfrage. Leipzig und Berlin: B.G. Teubner Verlag.

Koschmieder, Erwin 1930. Durchkreuzungen von Aspekt- und Tempussystem im Präsens. Zeitschrift für slavische Philologie VII. 341-358.

Koschmieder, Erwin. 1945. Zur Bestimmung der Funktionen grammatischer Kategorien. München: Verlag der Bayerischen Akademie der Wissenschaften.

Kwon, Iksoo. 2013. One-Mi: An evidential, epistemic modal, and focus marker in Imbabura Quechua. Survey reports, survey of California and other Indian languages. Berkeley: University of California. http://linguistics.berkeley.edu/ survey/documents/surveyreports/survey-report-15.05-kwon.pdf (accessed 30 July 2018). 
Langacker, Ronald. 2001. Cognitive linguistics, language pedagogy, and the English present tense. In Martin Pütz, Susanne Niemeier \& René Dirven (eds.), Applied cognitive linguistics I, 3-41. Berlin/New York: Mouton de Gruyter.

Łaziński, Marek 2014. The Aspect of Polish Performatives against the Background of Politeness Rules. Zeitschrift für Slavische Philologie, 327-343.

Leech, Geoffrey. 1971. Meaning and the English verb. London: Longmans.

Lin, William Chin-Juong. 1979. A descriptive semantic analysis of the Mandarin aspect-tense system. Ithaca, New York: Cornell University dissertation.

Manahlot, Demissie. 1988. Some notes on Amharic performative verbs. Proceedings of the Eighth International Conference of Ethiopian Studies. 1, 623-628. Addis Ababa: University of Addis Ababa.

Marmorstein, Michael. 2016. Tense and text in Classical Arabic: A discourse-oriented study of the Classical Arabic Tense system. Leiden: Brill.

Marmorstein, Michael. 2018. Reconsidering the 'perfect' - 'imperfect' opposition in the classical Arabic verbal system. In Mauro Tosco (ed.), Afroasiatic. data and perspectives (Current issues in linguistic theory 339), 61--84. Amsterdam/Philadelphia: John Benjamins Publishing Company.

Martin, Samuel E. 2004. A Reference Grammar of Japanese. Honolulu: University Of Hawai’i Press.

Mayer, Werner R. 1976. Untersuchungen zur Formensprache der Babylonischen Gebetsbeschwörungen, (Studia Pohl, series maior 5). Roma: Pontificium Institutum Biblicum.

Mayer, Werner R. 1992. Das “gnomische Präteritum” im literarischen Akkadisch. Orientalia Nova Series 61. 373-399.

Mberamihigo, Ferdinand. 2014. L'expression de la modalité en kirundi. Exploitation d'un corpus électronique. Bruxelles and Gand: Université libre de Bruxelles and Université de Gand (Universiteit Gent) Dissertation.

Mennecier, Philippe. 2016. Aspect-tense relations in East Greenlandic. Aspectuality and Temporality: Descriptive and Theoretical Issues 172. 297-323.

Michatk, Frido. 1959. Über den Aspekt in der obersorbischen Volkssprache. Zeitschrift für Slawistik 4(1). 241-253.

Miyaoka, Osahito. 2012. A grammar of Central Alaskan Yupik (CAY). Berlin: De Gruyter Mouton.

Mughazy, Mustafa. 2011. Performatives. In Lutz Edzard \& Rudolf de Jong (managing editors. online edition), Encyclopedia of Arabic Language and Linguistics. Leiden: Brill. http://dx. doi.org.ezproxy.leidenuniv.nl:2048/10.1163/1570-6699_eall_EALL_COM_vol3_0252 (accessed 11 March 2018).

Naïm, Samia. 2016. On interaction between external and internal markers in expressing aspect in Arabic dialect varieties. In Zlatka Guentchéva (ed.), Aspectuality and temporality: Descriptive and theoretical issues, 325-354. Amsterdam/Philadelphia: John Benjamins Publishing Company.

Nchare, Abdoulaye L. 2012. The grammar of Shupamem. New York: New York University dissertation.

Nedjalkov, Vladimir P. \& Sergej Je Jaxontov. 1988. The Typology of resultative constructions. In Nedjalkov (ed.), Typology of resultative constructions, 3-62. Amsterdam, Philadelphia: John Benjamins Publishing Company.

Nforbi, Emmanuel. 1993. Oku verb morphology: tense, aspect and mood. Yaounde: Yaounde University dissertation. 
Nkurikiye, Sylvestre. 1991. The pragmatics of Kirundi marriage discourse: Speech acts and discourse strategies. Munice, Indiana: Ball State University dissertation.

Peña, Jaime. 2015. A Grammar of Wampis. University of Oregon dissertation. https://scholars bank.uoregon.edu/xmlui/handle/1794/19730 (Accessed 30 July 2018).

Perry, John. 2005. A Tajik Persian reference grammar. Leiden: Brill.

Perry, John. 2007. Iranian languages: Modern Persian morphology. In Allan Kayne (ed.), Morphologies of Asia and Africa, vol. 2, 975-1019. Winona Lake, Indiana: Eisenbrauns.

Rattanapitak, Ampika. 2013. Request strategies in Burmese. Linguistics of the Tibeto-Burman Area 36(1). 73-90.

Recanati, François. 1987. Meaning and force: The pragmatics of performative utterances, Cambridge Studies in Philosophy. Cambridge: Cambridge University Press.

Robert, Stéphane. 2016. Tense and aspect in the verbal system of Wolof. In Zlatka Guentchéva (ed.), Aspectuality and temporality: Descriptive and theoretical issues, 171-230. Amsterdam/Philadelphia: John Benjamins Publishing Company.

Rogland, Max Frederik. 2003. Alleged non-past uses of qatal in classical Hebrew. Assen: Van Gorcum.

Rosaldo, Michelle. 1982. The Things We Do with Words: Ilongot Speech Acts and Speech Act Theory in Philosophy. Language in Society 11(2). 203-237.

Rubin, Aaron. 2018. Omani Mehri: A New Grammar with Texts. Leiden/Boston: Brill.

Sadock, Jerrold M. \& Arnold M. Zwicky. 1985. Speech Act distinctions in syntax. In Timothy Shopen (ed.), Language typology and syntactic description, vol. I, 155-196. Cambridge: Cambridge University Press.

Searle, John. 1975. A taxonomy of illocutionary acts. In Keith Gunderson (ed.), Language, mind, and knowledge, 344-369. Minneapolis: University of Minnesota Press.

Senft, Gunter. 1986. Kilivila, the Language of the Trobriand Islanders, (Mouton Grammar Library, 3). Berlin: Mouton de Gruyter.

Škrabec, Stanislav. 1903. Zum Gebrauche der Verba perfectiva und imperfectiva im Slovenischen. Archiv für Slavische Philologie 25. 554-564.

Slavkova, Svetlana. 2014. Performativnoe upotreblenie glagolov prosit'/poprosit' i molja/ pomolja v russkom i bolgarskom jazykax: Pragmatičeskaja rol' vida i vremeni ['Performative use of the verbs prosit'/poprosit' and molja/pomolja ('ask') in Russian and Bulgarian: The pragmatic role of verbal aspect and tense']. Scando-Slavica 60(2). 231-252.

Slavkova, Svetlana. 2017. Tense and aspect in performative utterances in Bulgarian. Advances in Social Science, Education and Humanities Research, volume 142. https://www.atlantispress.com/proceedings/icelaic-17/25886279 (accessed 30 July 2018).

Smyth, Herbert Weir. 1920. A Greek grammar for colleges. http://www.perseus.tufts.edu/hop per/text?doc=Perseus\%3Atext\%3A1999.04.0007\%3Apart\%3D4\%3Achapter\%3D44\% 3Asection\%3D111\%3Asubsection\%3D124 (accessed 30 July 2018).

Soga, Matsuo. 1983. Tense and aspect in modern colloquial Japanese. Vancouver: University of British Colombia Press.

Stunová, Anna. 1994. Czech and Russian aspect in the historical present. In Adriaan A. Barentsen, Ben M. Groen \& Rob Sprenger (eds.), Studies in Slavic and General Linguistics Vol. 22, Dutch Contributions to the Eleventh International Congress of Slavists. Linguistics, 407-431, Amsterdam, Atlanta GA: Rodopi.

Svantesson, Jan-Olof. 1991. Tense, mood and aspect in Mongolian. Working Papers in Linguistics 38. 189-204. 
Sxaken, Jos, Ègbert Fortejn \& Simeon Dekker. [= Schaeken, Jos, Egbert Fortuin and Simeon Dekker]. 2014. Ėpistoljarnyj dejksis v novgorodskix berestjanyx gramotax [Epistolary deixis in Novgorodian birch bark texts]. Voprosy jazykoznanija 1. 21-38.

Toews, Carmela. 2015. Topics in Siamou tense and aspect. Vancouver: University of British Columbia dissertation.

Verschueren, Jef. 1995. The conceptual basis of performativity. In Masayoshi Shibatani \& Sandra A. Thompson (eds.), Essays in Semantics and Pragmatics, 299-321. Amsterdam/ Philadelphia: John Benjamins Publishing Company.

Vinogradov, Igor. 2016. Acerca de la semántica del completivo/incompletivo en las lenguas mayas. Cuadernos de Lingüística de El Colegio de México 3(1). 5-44.

Volodin, Aleksandr. 1988. Resultative and perfect passive in Finnish. In Vladimir P. Nedjalkov (ed.), Typology of resultative constructions, 469-477. Amsterdam, Philadelphia: John Benjamins.

Von Soden, Wolfram. 1995. Grundriss der akkadischen Grammatik, 3. (ergänzte Auflage. Unter Mitarbeit von Werner R. Mayer). Roma: Editrice Pontificio Istituto Biblico Roma.

Welmers, William, E. 1973. African Language Structures. Berkeley: University of California Press. Wiedenhof, Jeroen. 2004. Grammatica van het Mandarijn. Amsterdam: Uitgeverij BULAAQ.

Wiemer, Björn. 2014. Upotreblenie soveršennogo vida v performativnom nastojaščem. In S.J u. Dmitrenko \& N.M. Zaika (eds.), Studia octogenario Victori Khrakovskij Samuelis filio dedicata (Acta linguistica Petropolitana 10 (3)), 91-113. St Petersburg: Nauka.

Wierzbicka, Anna. 1991. Cross-cultural pragmatics: The semantics of human interaction, (Trends in Linguistics. Studies and Monographs 53). Berlin: Mouton de Gruyter.

Yu, Kyong-Ae. 2011. Culture-specific concepts of politeness: Indirectness and politeness in English, Hebrew and Korean requests. Intercultural Pragmatics 8(3). 385-409.

Žagar, Igor. 2003. Teorija performativnosti pri Stanislavu Skrabcu. In J. Toporišlč (ed.), Države, pokrajine, narodi, ljudstva in njih kulture ter znanosti v Skrabčevih delih: Skrabčeva misel IV: Zbornik s simpozija 2002, 219-229. Nova Gorica: Frančiškanski samostan Kostanjevica. http://www.samostan-kostanjevica.si/sites/default/files/Didknj-data/igor\%20zagar-4.pdf (accessed 30 July 2018).

Žagar, Igor. 2011. Performativity as tense and aspect. International Review of Pragmatics 3(2). 168-193.

Zeisler, Bettina. 2004. Relative tense and aspectual values in Tibetan languages: A comparative study. vol. 150. Berlin/New York: Mouton de Gruyter.

\section{Other references}

Corpus Brieven als Buit [Letters as Loot]. http://brievenalsbuit.inl.nl/zeebrieven/page/search. Electronic text corpus of Sumerian Literature (ETCSLtranslation: t.1.8.1.1. http://etcsl.orinst.ox. ac.uk/cgi-bin/etcsl.cgi?text=t.1.8.1.1\#).

Supplementary Material: The online version of this article offers supplementary material (DOI: https://doi.org/10.1515/lingty-2018-0018). 